\title{
AKTA PRZEWODÓW DOKTORSKICH I HABILITACYJNYCH WYDZIAŁU KOŚCIELNYCH NAUK HISTORYCZNYCH I SPOLECZNYCH ATK
}

Archiwum Uniwersytetu Kardynała Stefana Wyszyńskiego w Warszawie jest archiwum zakładowym z prawem przechowywania zasobu historycznego (akta kategorii A) ${ }^{1}$. Jego zasób tworzy zespół złożony akt Akademii Teologii Katolickiej w Warszawie (ATK) z lat 1954-1999 oraz Uniwersytetu Kardynała Stefana Wyszyńskiego w Warszawie (UKSW), który powstał w wyniku przekształcenia ATK w 1999 r. Akta w Archiwum UKSW pogrupowane są według registratur uczelni - wydziałów i jednostek ogólnouczelnianych, jak Biuro Rektorskie, Dział Kadr, Kwestura itp. Akta przekazane od 2000 r. - daty powstania Archiwum - posiadają pomoce ewidencyjne w postaci spisów zdawczo-odbiorczych. Wśród nich znajdują się zarówno akta studenckie, jak i akta organizacji i zarządzania uczelnią i poszczególnymi wydziałami (protokoły obrad Senatu ATK i UKSW, protokoły posiedzeń rad wydziałów). Cenną część zasobu stanowią też akta dokumentujące rozwój naukowy uczelni, w tym przede wszystkim akta przewodów doktorskich i habilitacyjnych. Niniejsze opracowanie źródłowe ma na celu przedstawienie akt przewodów doktorskich i habilitacyjnych, powstałych na Wydziale Kościelnych Nauk Historycznych i Społecznych ATK. Ułatwi to podjęcie badań zarówno nad działalnością naukową na tym wydziale - który w UKSW funkcjonuje jako Wydział Nauk Historycznych i Społecznych - jak i przyczyni się do poznania dziejów całej uczelni.

Akademia Teologii Katolickiej powstała w 1954 r. poprzez wyodrębnienie z Uniwersytetu Warszawskiego Wydziału Teologii Katolickiej (WTK) i dołączenie do niego Wydziału Teologicznego Uniwersytetu Jagiellońskiego. Przez większą część historii ATK funkcjonowały na uczelni trzy wydziały, powstałe z katedr WTK. Były to: Wydział Teologiczny, Wydział Filozofii Chrześcijańskiej

* Dariusz Milewski - dr historii, adiunkt w Instytucie Nauk Historycznych UKSW, Warszawa.

${ }^{1}$ Prawo do przechowywania zasobu historycznego daje Archiwum Ustawa z dnia 14 lipca 1983 roku o narodowym zasobie archiwalnym i archiwach, art. 35, pkt. 2 (Dz.U. 1983, nr 38, poz. 173 z późn. zmianami). 
i Wydział Prawa Kanonicznego. W ramach Wydziału Teologicznego uprawiane były również dyscypliny, wchodzące w skład tzw. kościelnych nauk historycznych. Były to zatem historia Kościoła, patrologia, muzykologia oraz archeologia chrześcijańska. Rozwój badań w tym zakresie, wzrost liczby studentów oraz wykładowców, zachęciły władze uczelni do podjęcia starań o wyodrębnienie tych kierunków z Wydziału Teologicznego i powołanie nowego wydziału. Starania te zostały uwieńczone powodzeniem w 1987 r. Wtedy to powołano Wydział Kościelnych Nauk Historycznych i Społecznych ${ }^{2}$.

Nowy wydział od początku miał prawo do nadawania stopni doktora i doktora habilitowanego. Po Wydziale Teologicznym „odziedziczy”” zresztą 13 otwartych przewodów doktorskich ${ }^{3}$. Dziedzictwo teologiczne wyrażało się także w kierunkach prac badawczych - prace doktorskie powstawały głównie w zakresie historii Kościoła, historii sztuki, muzykologii kościelnej, archeologii chrześcijańskiej i patrologii. Stopniowo coraz większy udział zdobywały sobie prace z zakresu chrześcijańskich nauk społecznych i socjologii religii. Wśród doktoratów nostryfikowanych na Wydziale, zdecydowaną przewagę uzyskały prace z zakresu patrologii (osiem nostryfikacji na dziesięć ogółem). Daje się również zauważyć - zwłaszcza w początkowym okresie działalności Wydziału - wyraźna specjalizacja wśród promotorów. I tak, przykładowo, znaczną część prac z historii sztuki promował prof. Janusz Pasierb, z historii Kościoła prof. Eugeniusz Wyczawski, zaś z muzykologii - prof. Jerzy Pikulik (zob. tabela 1). Ogółem zasób aktowy przewodów doktorskich WKNHiS, przechowywany w Archiwum UKSW, obejmuje 95 jednostek archiwalnych. Mniejsza jest - co zrozumiałe - liczba przewodów habilitacyjnych. W Archiwum UKSW składa się na nie 21 jednostek archiwalnych. W obu przypadkach w skład jednostki archiwalnej wchodzą akta przewodu, począwszy od podania doktoranta do Rady Wydziału o otwarcie przewodu doktorskiego bądź habilitacyjnego, a skończywszy na odpisie do akt dyplomu bądź zaświadczeniu o nostryfikacji dyplomu. Integralną częścią akt jest praca doktorska lub habilitacyjna - jej ewentualny brak w aktach zawsze odnotowano. Akta znajdują się w odpowiednio opisanych i opatrzonych sygnaturami teczkach. Akta doktorskie zostały już opracowane i spaginowane.

Akta przewodów doktorskich WKNHiS w Archiwum UKSW obejmują zarówno akta przewodów otwartych i zakończonych na Wydziale, jak i akta nostryfikacji dyplomów doktorskich, uzyskanych na uczelniach zagranicznych. Jest to w sumie 89 jednostek archiwalnych. Uzupełniają je akta przewodów otwartych, ale z różnych przyczyn niezakończonych -6 jednostek archiwalnych. Łącznie obejmują one lata 1973-1999. Niemal cała dokumentacja znalazła się w posiadaniu Archiwum w chwili jego powstania i brakuje dla niej spisów zdawczo-od-

${ }^{2}$ Stało się to na mocy Zarządzenia nr 12 Ministra Nauki i Szkolnictwa Wyższego z dnia 16 VI 1987 r., które wchodziło w życie 1 VII 1987 r. Zob. Archiwum UKSW (dalej: AUKSW), Protokoły Rady Wydziału Teologicznego ATK, sygn. WT/34, s. 136 (protokół z posiedzenia Rady Wydziału Teologicznego ATK z dnia 29 czerwca 1987 r.).

${ }^{3}$ Były to przewody doktorskie T. Czapiewskiego, J. Myszora, K. Treli, T. Czapigi, A. Filabera, J. L. Kontkowskiego, M. Biernackiej, K. Gruczyńskiego, H. Podgórskiej, L. Nowaka, T. Dziubeckiego, S. Ryszkowskiego i T. Gebhardta (zob. tabela 1). 
biorczych. Jedynie akta przewodu doktorskiego Janusza Nowińskiego przekazane zostały do Archiwum w 2006 r. na odrębnym spisie, wraz z aktami przewodów doktorskich WNHiS (spis nr 7/2005). Całość dokumentacji przedstawiono w tabeli nr 1. Składa się ona z ośmiu kolumn - pierwszej porządkowej i siedmiu tematycznych. Akta uszeregowano zgodnie z ich sygnaturami, według przeprowadzonego w Archiwum porządkowania i opracowania. Jest to zatem ustawienie chronologiczne. Odbiega od niego tylko ostatnia pozycja - wzmiankowane wyżej akta przewodu doktorskiego J. Nowińskiego. W związku z przekazaniem ich na odrębnym spisie i opatrzeniu stosowną sygnaturą (WHS-7/1), znalazły się one na końcu tabeli.

W swej części tematycznej tabela obejmuje siedem kolumn. Ich układ oraz treść mają odzwierciedlić najistotniejsze elementy przewodu doktorskiego i służyć przede wszystkim przyszłym badaczom dziejów nauki i Wydziału. Dlatego też pominięto kwestie nieistotne $\mathrm{z}$ tego punktu widzenia, a charakterystyczne dla archiwalnego opisu akt, jak stan zachowania akt, język dokumentów itp. ${ }^{4}$ W pierwszej z kolumn tematycznych tabeli (kolumna nr 2) zaznaczono sygnaturę akt. Jest to sygnatura tymczasowa, ponieważ cały zespół ATK/UKSW, jako zespół złożony i otwarty, nie może być jeszcze w całości opracowany. Sygnatura obejmuje skróconą nazwę Wydziału, stosowaną w registraturze (WHS) oraz numer porządkowy akt (a więc WHS/1, WHS/2 itd.). W przypadku przekazania akt na spisie, sygnatura składa się ze skrótu nazwy Wydziału, numeru spisu i numeru pozycji na spisie, odpowiadającej danym aktom (np. WHS-7/1). W kolejnej kolumnie (nr 3) podano nazwisko doktoranta. Kolumna 4. zawiera temat pracy, liczbę stron dla każdego tomu pracy oraz - w razie konieczności - liczbę ilustracji. Temat pracy pochodzi ze strony tytułowej - w razie braku pracy w aktach, temat zaczerpnięto $\mathrm{z}$ akt przewodu. W kolumnie 5. podano specjalność, w jakiej nadany został stopień doktora - zgodnie $\mathrm{z}$ urzędowym zawiadomieniem o nadaniu stopnia doktora, znajdującym się w aktach. W kolumnie 6. podano nazwisko promotora - bądź promotorów, jeśli w trakcie przewodu nastąpiła zmiana. W przypadku nostryfikacji odnotowano ten fakt właśnie w tej kolumnie. W kolumnie 7. podano nazwiska recenzentów. Kolumna 8. obejmuje cztery informacje: datę otwarcia przewodu doktorskiego, datę obrony pracy, datę uchwały Rady Wydziału o nadaniu stopnia doktora oraz datę i numer dyplomu doktorskiego. W tym ostatnim przypadku na dyplomie wypisywano numer kolejny z księgi dyplomów doktorskich ATK, następnie skróconą nazwę Wydziału i numer kolejny dyplomu doktorskiego, uzyskanego na Wydziale. Dopiero w 1997 r. nastąpiło odejście od tego zwyczaju i począwszy od doktoratu ks. Piotra Mazurkiewicza na dyplomie pisano tylko numer kolejny z księgi dyplomów doktorskich ATK. W przypadku czterech pierwszych nostryfikacji sytuacja jest analogiczna. Dopiero od nostryfikacji dyplomu doktorskiego ks. Tomasza Skibińskiego w 1996 r. zaczęto wpisywać numer zaświadczenia zamiast numeru kolejnego z księgi dyplomów doktorskich. Brak w kolumnie 8. którejś z dat oznacza, iż odnośnego aktu nie znaleziono w teczce

${ }^{4}$ Sprawy te zostały uwzględnione w Inwentarzu Zespołów Archiwalnych (IZA), tworzonym w Archiwum UKSW. 
bądź też - co następuje w przypadku przerwania przewodu doktorskiego - nie doszło do powstania danego aktu. Jeśli Rada Wydziału podjęła decyzję o przerwaniu przewodu doktorskiego, data tej decyzji znajduje się na pozycji 2. i jest oznaczona informacją [przerwanie przewodu dr].

Podobny układ ma tabela, prezentująca akta przewodów habilitacyjnych WKNHiS, przechowywanych w Archiwum UKSW. Pominiemy zatem jej szczegółowy opis, poprzestając tyko na zaznaczeniu najważniejszych różnic. Tabela składa się z siedmiu kolumn - pierwszej porządkowej i sześciu tematycznych. Przedstawione w niej akta zostały przekazane do Archiwum UKSW na jednym spisie w kwietniu 2005 r (spis nr 3/2005). Dlatego też wszystkie sygnatury składają się ze skrótu literowego Wydziału, numeru spisu i numeru pozycji na spisie (np. WHS-3/1). Niestety, w ramach spisu nie zachowano porządku chronologicznego. Przy niniejszej prezentacji materiału źródłowego przedstawiono jednak akta zgodnie $\mathrm{z}$ ich ułożeniem w ramach spisu, kierując się chęcią oddania rzeczywistego stanu rzeczy i zachowania porządku sygnatur. Na spisie znalazły się 23 jednostki archiwalne, w tym dwie wpisane omyłkowo - są to akta zatrudnienia na stanowiska naukowe na Wydziale. Dlatego też pominięto je tutaj ${ }^{5}$. Tabela obejmuje zatem 21 przewodów habilitacyjnych o sygnaturach od WHS-3/1 do WHS-3/23 z lat 1988-1999. W kolumnie 3. podano nazwisko habilitanta. Kolumna 4. podaje temat pracy, miejsce i rok wydania oraz liczbę stron. W kolumnie 5. zaznaczono specjalność, w jakiej nadany został stopień doktora habilitowanego, a w kolumnie 6. podano nazwiska recenzentów pracy habilitacyjnej (z reguły trzy osoby). Kolumna 7. zawiera cztery informacje: 1) datę otwarcia przewodu habilitacyjnego, 2) datę kolokwium habilitacyjnego i uchwały Rady Wydziału o nadaniu stopnia doktora habilitowanego (odbywało się to tego samego dnia), 3) datę pisma Centralnej Komisji do Spraw Tytułu Naukowego i Stopni Naukowych, zatwierdzającego uchwałę Rady Wydziału o nadaniu stopnia doktora habilitowanego oraz 4) datę i numer dyplomu doktora habilitowanego. W przypadku numeru dyplomu stosowano na Wydziale praktykę analogiczną do numerowania dyplomów doktorskich.

Przedstawiony materiał źródłowy, przybliżając tylko jeden z aspektów - choć istotny - działalności naukowej na Wydziale Kościelnych Nauk Historycznych i Społecznych ATK, wypełnia pewną lukę w znajomości dziejów Wydziału. Zarazem jednak ma on stanowić dopiero wstęp i zachętę dla przyszłych badaczy tego problemu, dając im wykaz omawianego typu dokumentacji.

${ }^{5}$ Są to akta T. Trajdosa, AUKSW, sygn. WHS-3/7 i A. Marcola, AUKSW, sygn. WHS-3/9. 


\begin{tabular}{|c|c|c|c|c|c|c|}
\hline 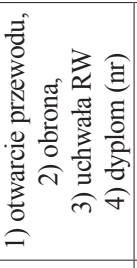 & 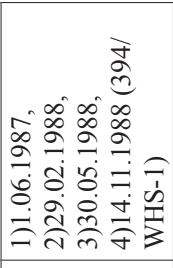 & 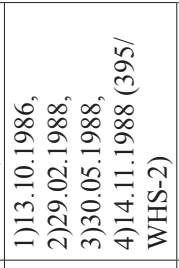 & 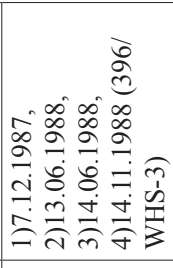 & 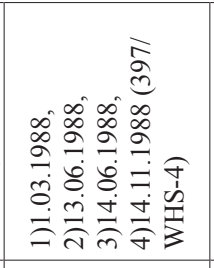 & 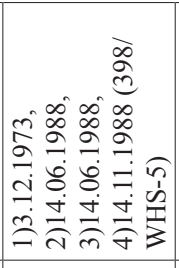 & 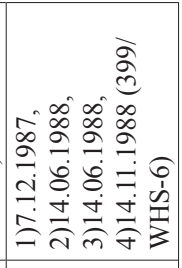 \\
\hline $\begin{array}{l}\overline{0} \\
\overline{\tilde{N}} \\
\overline{0} \\
\ddot{U} \\
\simeq\end{array}$ & 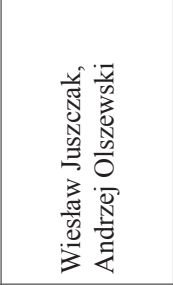 & 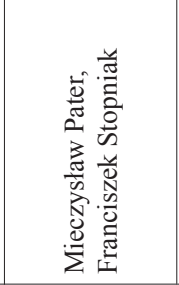 & 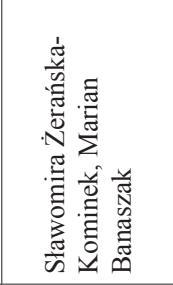 & 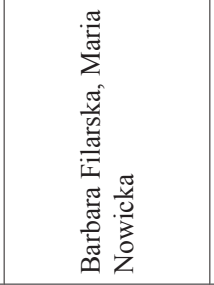 & 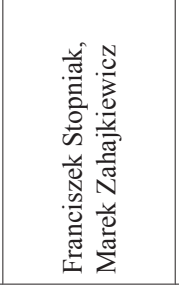 & 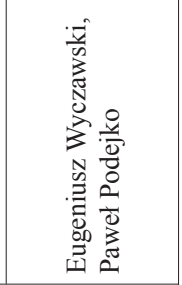 \\
\hline 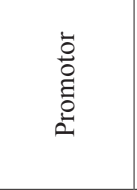 & 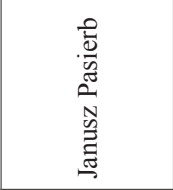 & 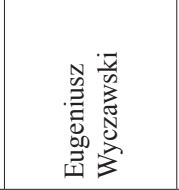 & 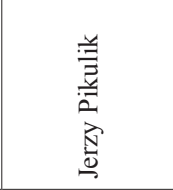 & 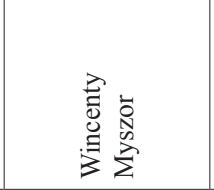 & 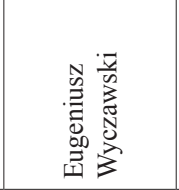 & 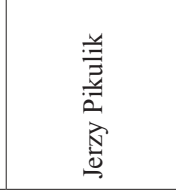 \\
\hline 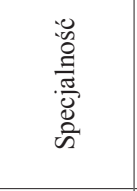 & 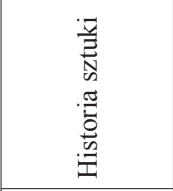 & 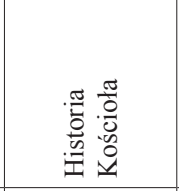 & 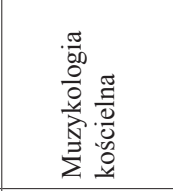 & 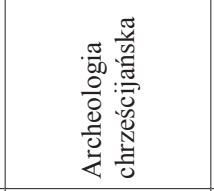 & 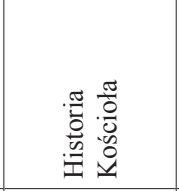 & 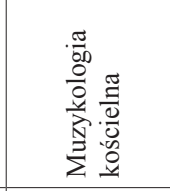 \\
\hline 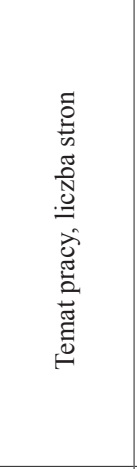 & 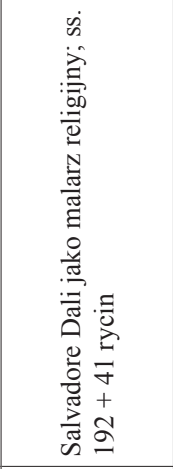 & 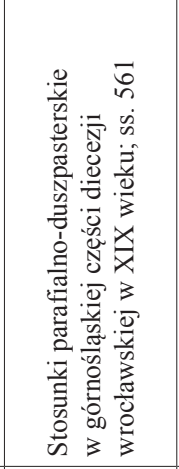 & 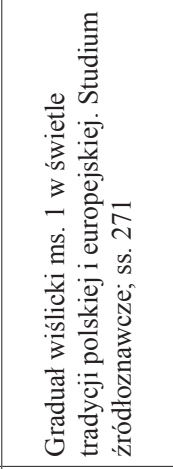 & 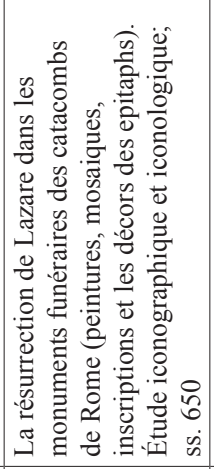 & 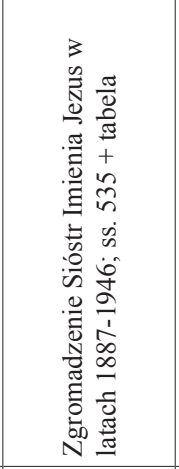 & 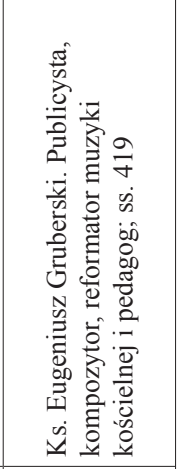 \\
\hline 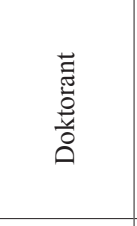 & 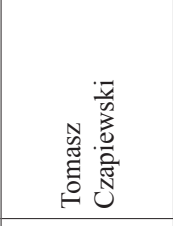 & 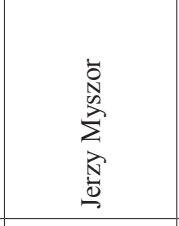 & 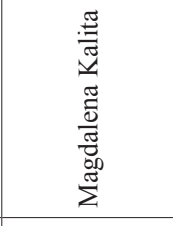 & 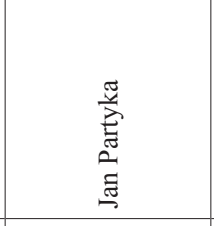 & 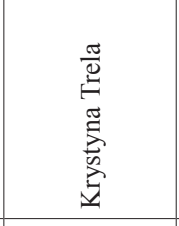 & 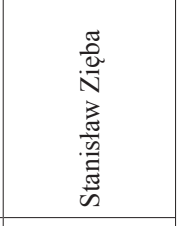 \\
\hline 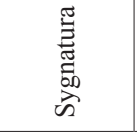 & $\overrightarrow{\vec{n}}$ & $\sum_{3}^{\infty}$ & $\sum_{3}^{0}$ & $\sum_{j}^{\infty}$ & $\sum_{3}^{\infty}$ & $\sum_{3}^{n}$ \\
\hline ن. & - & $N$ & $m$ & + & $n$ & 6 \\
\hline
\end{tabular}




\begin{tabular}{|c|c|c|c|c|c|c|}
\hline 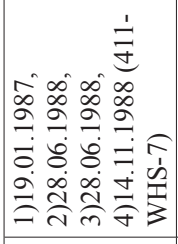 & 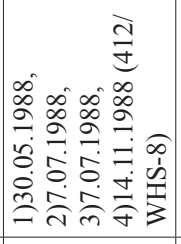 & 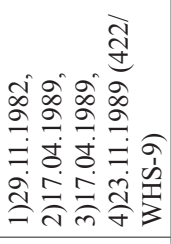 & 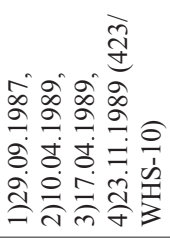 & 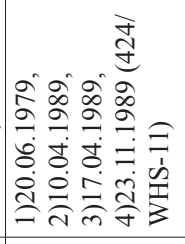 & 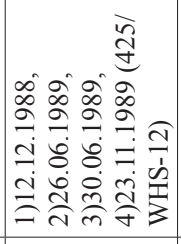 & 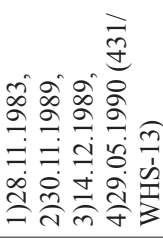 \\
\hline 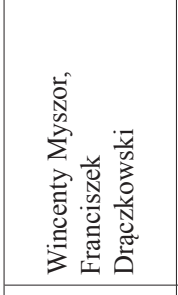 & 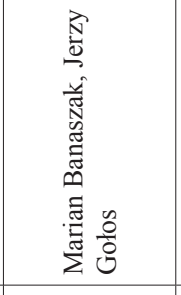 & 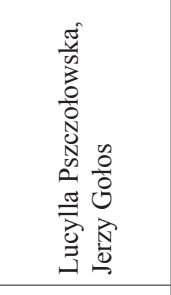 & 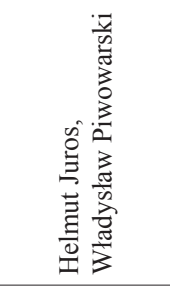 & 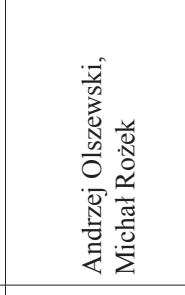 & 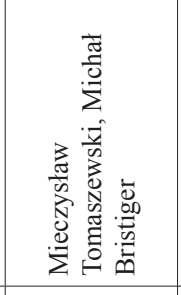 & 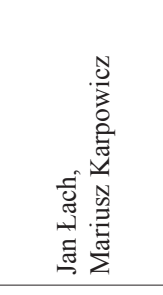 \\
\hline 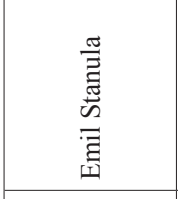 & 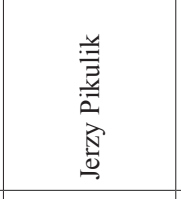 & 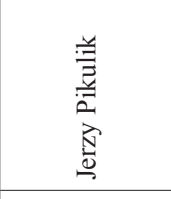 & 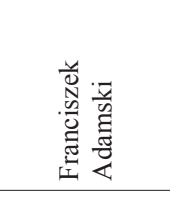 & 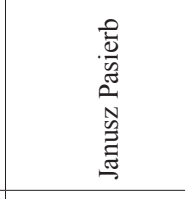 & 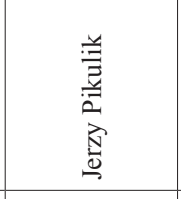 & 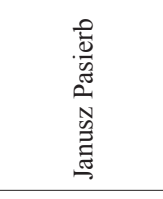 \\
\hline 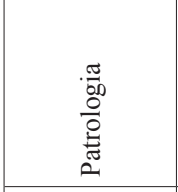 & 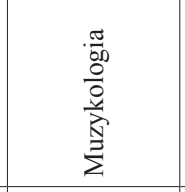 & 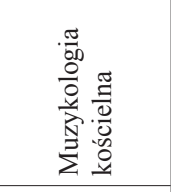 & 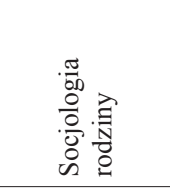 & 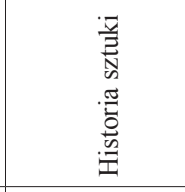 & $\begin{array}{l}\frac{\pi}{50} \\
\frac{0}{0} \\
\frac{0}{2} \\
\frac{1}{3} \\
\end{array}$ & 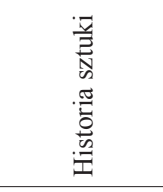 \\
\hline 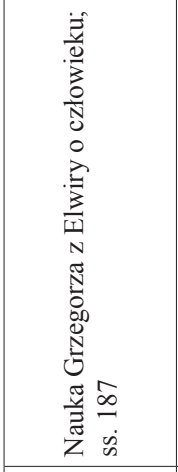 & 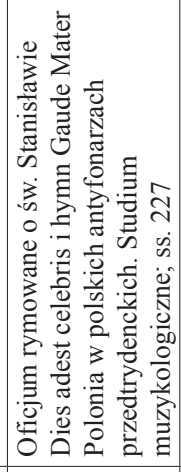 & 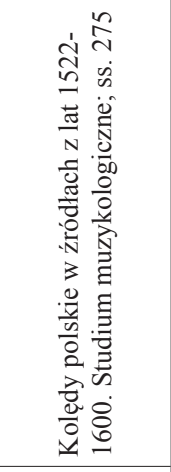 & 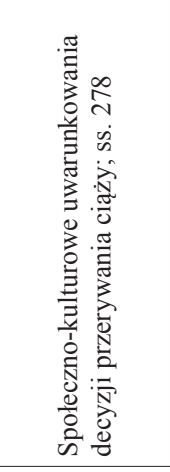 & 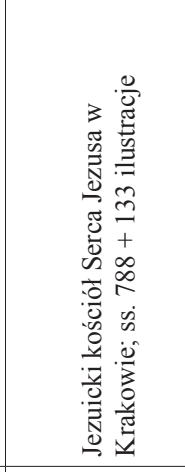 & 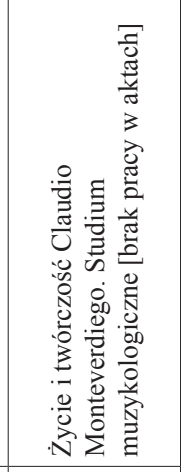 & 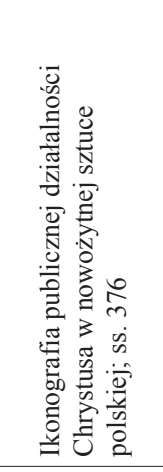 \\
\hline 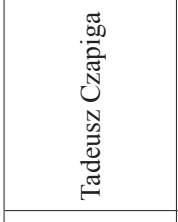 & 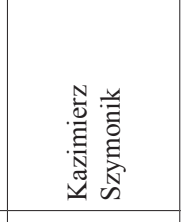 & 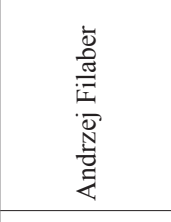 & 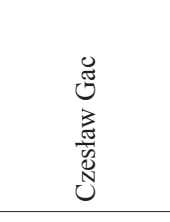 & 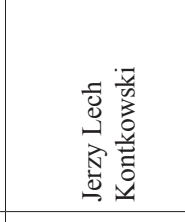 & 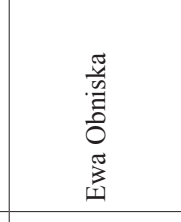 & 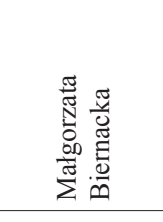 \\
\hline$\frac{5}{5}$ & 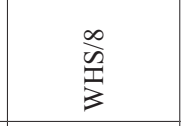 & $\frac{a}{5}$ & $\begin{array}{l}\frac{9}{5} \\
\text { 龺 } \\
\frac{3}{3}\end{array}$ & $\begin{array}{l}\overline{7} \\
\sum_{3}^{*}\end{array}$ & $\frac{1}{3}$ & $\frac{n}{n}$ \\
\hline$r$ & $\infty$ & $a$ & $\stackrel{\circ}{\circ}$ & $=$ & $\simeq$ & $\cong$ \\
\hline
\end{tabular}




\begin{tabular}{|c|c|c|c|c|c|c|}
\hline 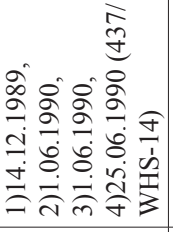 & 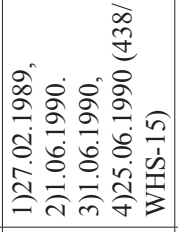 & 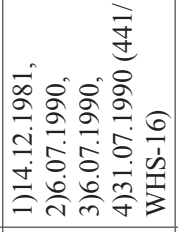 & 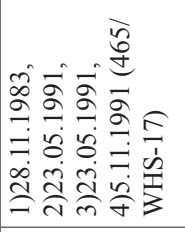 & 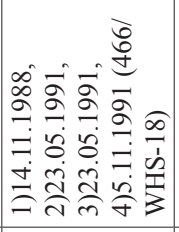 & 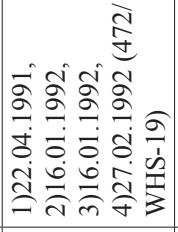 & 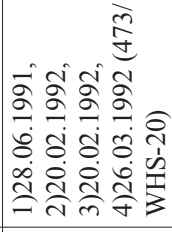 \\
\hline 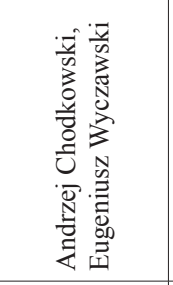 & 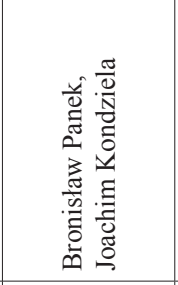 & 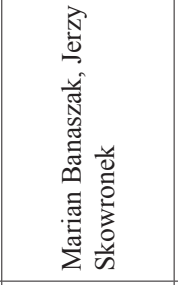 & 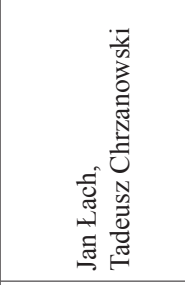 & 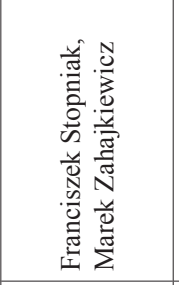 & 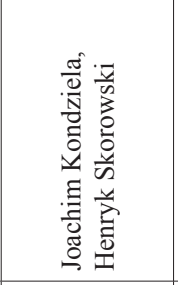 & 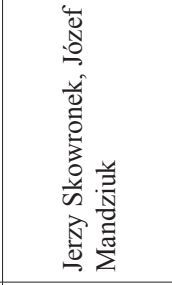 \\
\hline 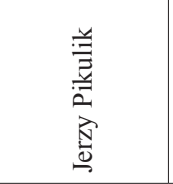 & 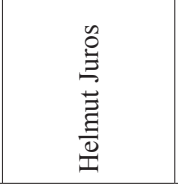 & 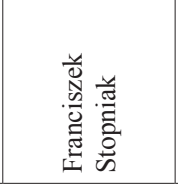 & 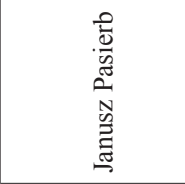 & 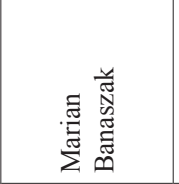 & 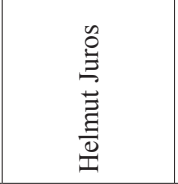 & 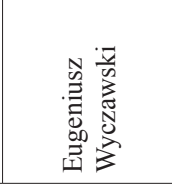 \\
\hline 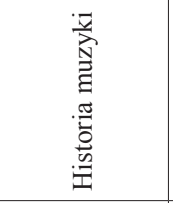 & 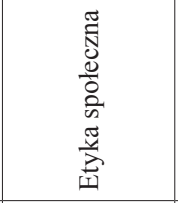 & 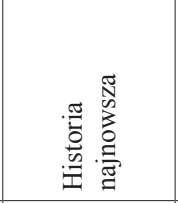 & 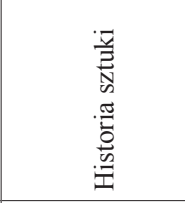 & 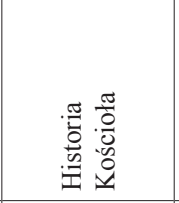 & 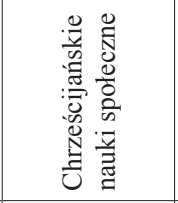 & 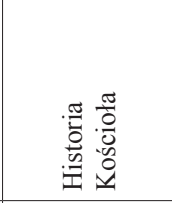 \\
\hline 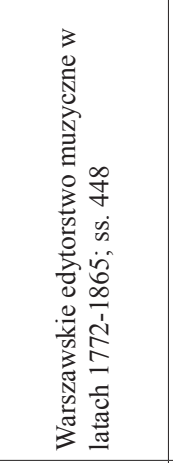 & 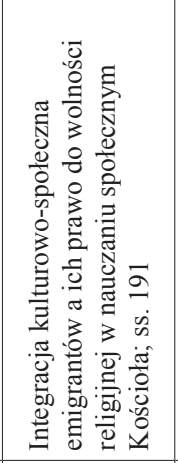 & 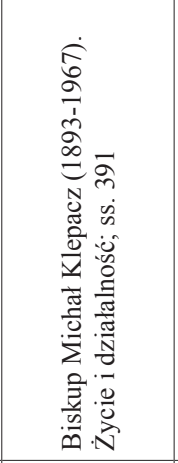 & 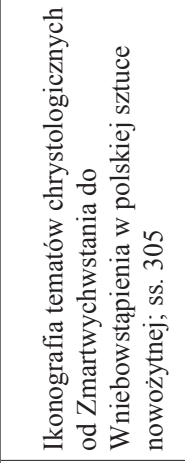 & 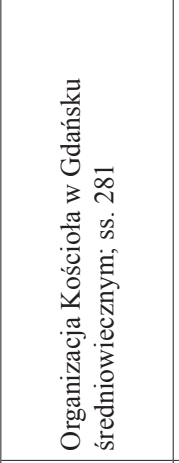 & 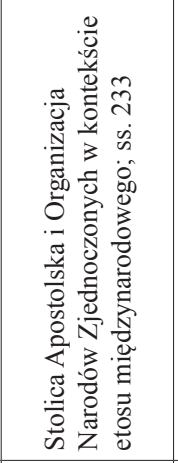 & 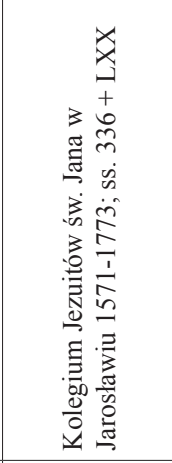 \\
\hline 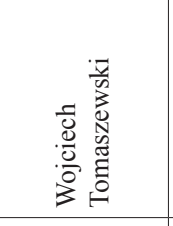 & 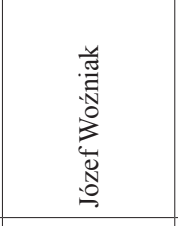 & 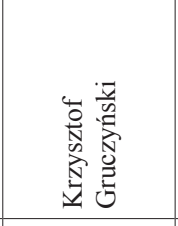 & 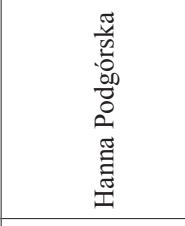 & 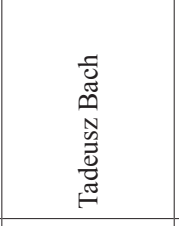 & 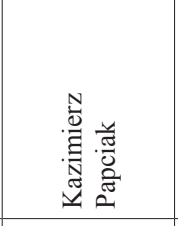 & 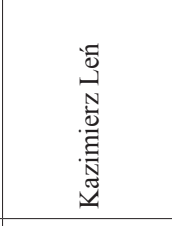 \\
\hline 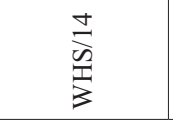 & $\frac{n}{\frac{n}{n}}$ & $\begin{array}{l}\frac{0}{\infty} \\
\frac{1}{3} \\
3\end{array}$ & $\frac{5}{\sqrt[5]{3}}$ & $\frac{\infty}{\stackrel{\infty}{\infty}}$ & $\begin{array}{l}\frac{a}{\sqrt[2]{2}} \\
\frac{1}{3}\end{array}$ & 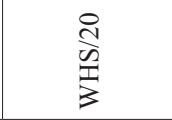 \\
\hline$\unlhd$ & $\because$ & $\because$ & $\beth$ & $\stackrel{\infty}{-}$ & $\approx$ & ¿ิ \\
\hline
\end{tabular}




\begin{tabular}{|c|c|c|c|c|c|c|}
\hline 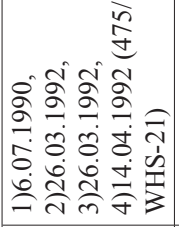 & 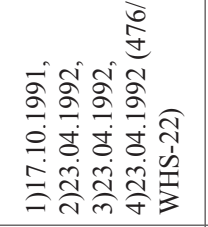 & 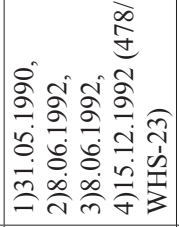 & 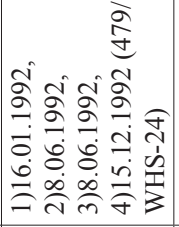 & 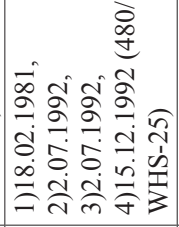 & 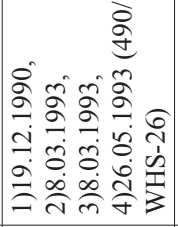 & 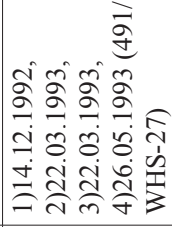 \\
\hline 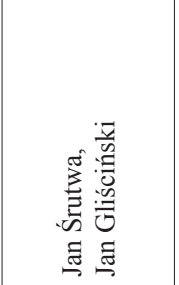 & 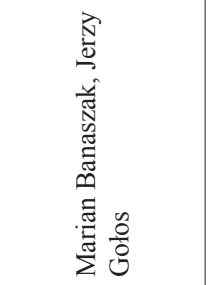 & 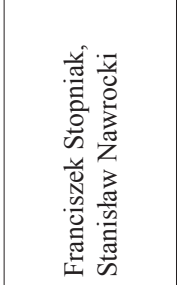 & 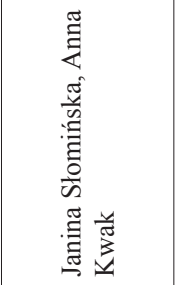 & 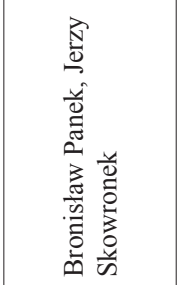 & 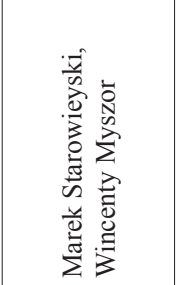 & 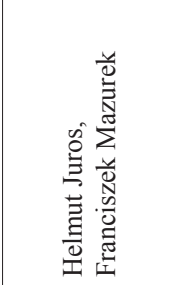 \\
\hline 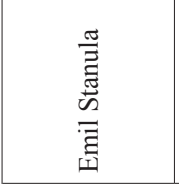 & 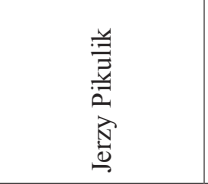 & 胥 & 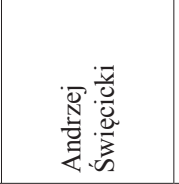 & 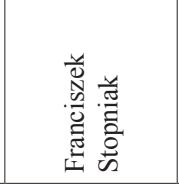 & 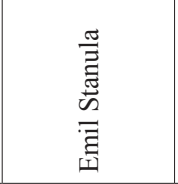 & 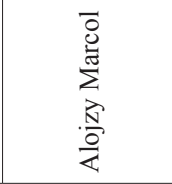 \\
\hline $\begin{array}{l}\frac{\pi}{60} \\
0 \\
0 \\
0 \\
0 \\
0\end{array}$ & 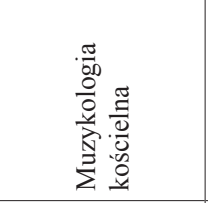 & 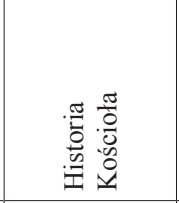 & 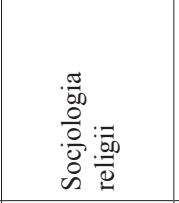 & 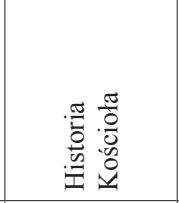 & $\begin{array}{l}\frac{\pi}{60} \\
0 \\
0 \\
0 \\
0 \\
0 \\
0\end{array}$ & 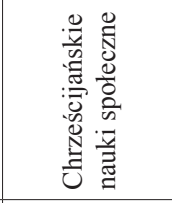 \\
\hline 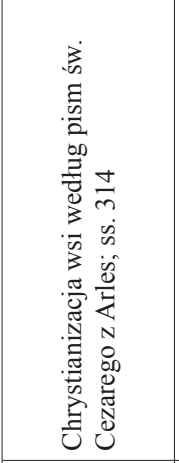 & 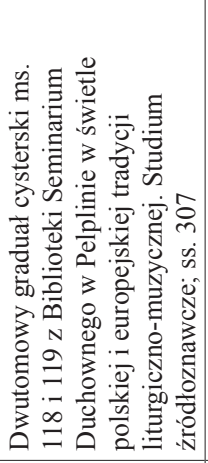 & 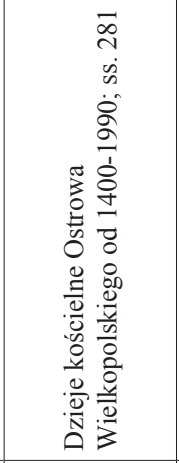 & 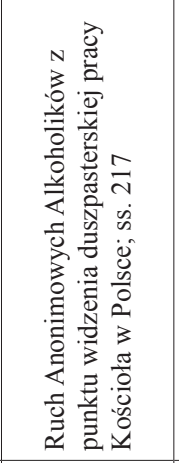 & 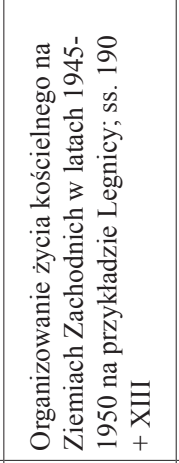 & 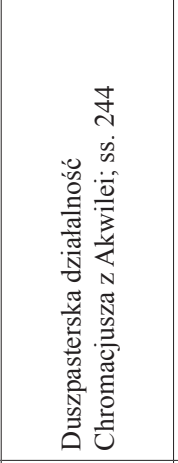 & 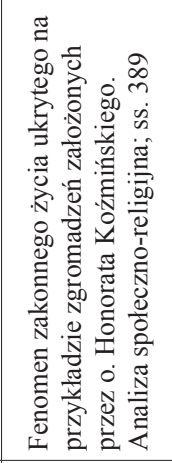 \\
\hline 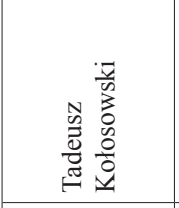 & 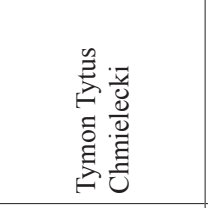 & 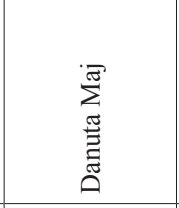 & 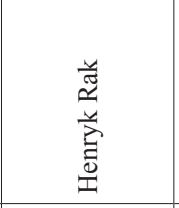 & 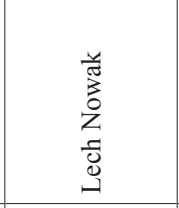 & 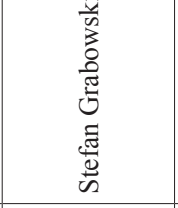 & 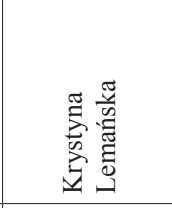 \\
\hline $\begin{array}{l}\vec{N} \\
\sqrt{n} \\
\frac{1}{3}\end{array}$ & $\begin{array}{l}\text { ปี } \\
\text { Wn } \\
3 \\
3\end{array}$ & 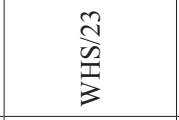 & $\begin{array}{l}\stackrel{+}{2} \\
\sqrt{2} \\
3 \\
3\end{array}$ & 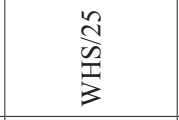 & 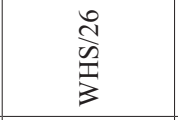 & 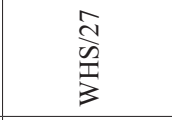 \\
\hline$\vec{\sim}$ & ป & $\sqrt{2}$ & 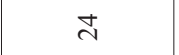 & $\tilde{a}$ & $\stackrel{\sim}{\sim}$ & 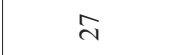 \\
\hline
\end{tabular}




\begin{tabular}{|c|c|c|c|c|c|c|}
\hline 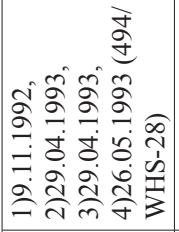 & 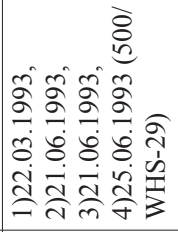 & 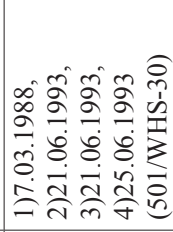 & 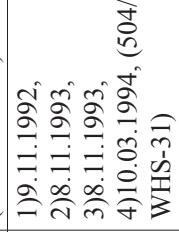 & 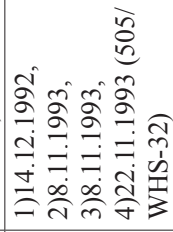 & 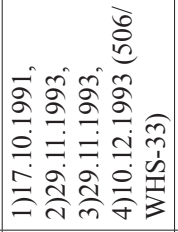 & 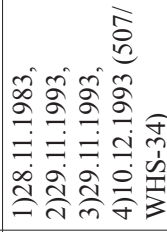 \\
\hline 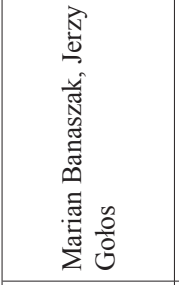 & 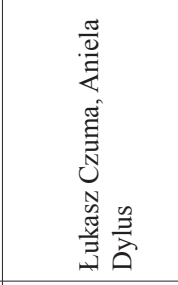 & 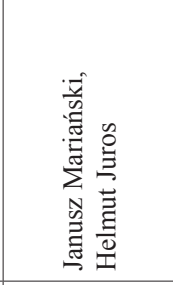 & 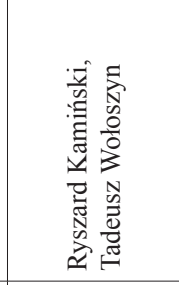 & 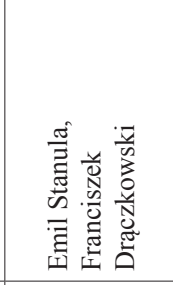 & 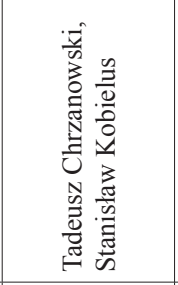 & 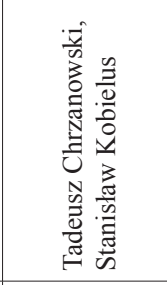 \\
\hline 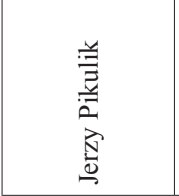 & 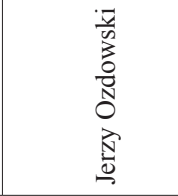 & 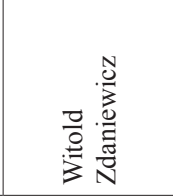 & 营营 & 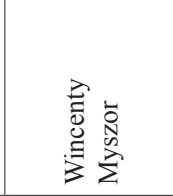 & 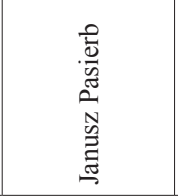 & 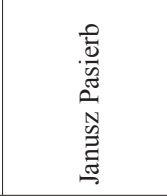 \\
\hline 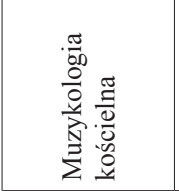 & 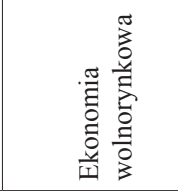 & 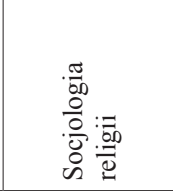 & 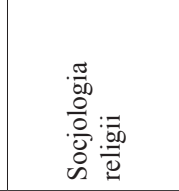 & $\begin{array}{l}\frac{\pi}{60} \\
\frac{0}{0} \\
0 \\
0 \\
0\end{array}$ & 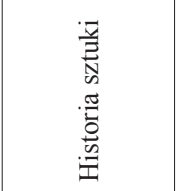 & 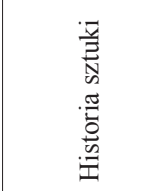 \\
\hline 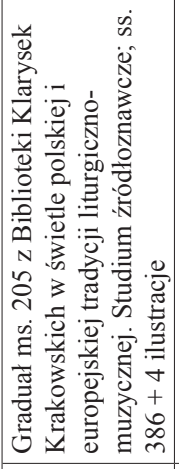 & 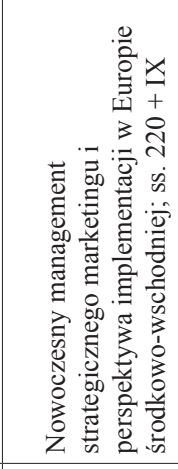 & 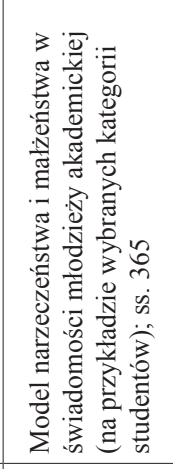 & 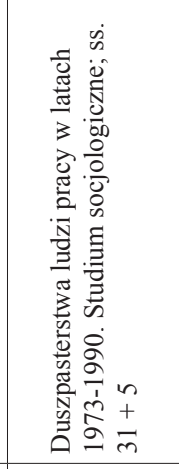 & 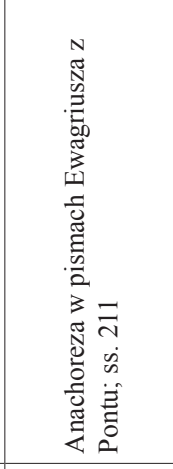 & 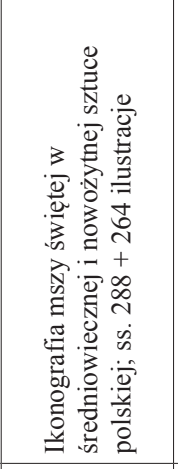 & 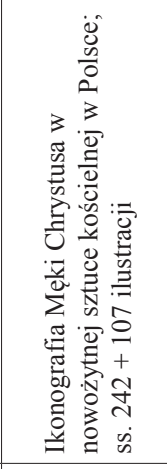 \\
\hline 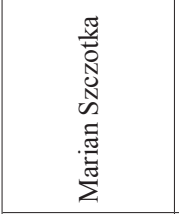 & 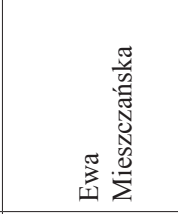 & 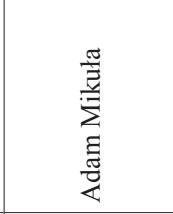 & 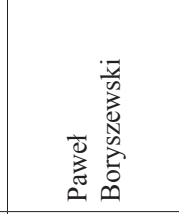 & 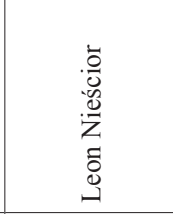 & 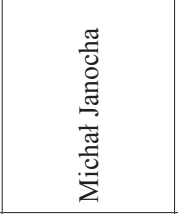 & 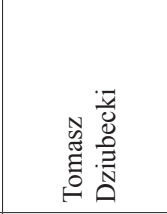 \\
\hline 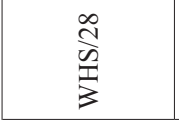 & $\frac{\substack{\frac{1}{\omega} \\
\frac{1}{3}}}{3}$ & $\begin{array}{l}\frac{1}{5} \\
\frac{1}{3} \\
3\end{array}$ & 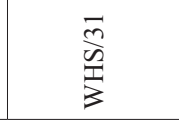 & $\frac{N}{\infty}$ & $\begin{array}{l}\frac{m}{n} \\
\frac{n}{3} \\
3\end{array}$ & 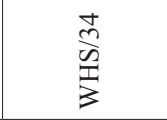 \\
\hline$\stackrel{\infty}{\sim}$ & ৯े & i & $\bar{m}$ & กี & $m$ & "ా \\
\hline
\end{tabular}




\begin{tabular}{|c|c|c|c|c|c|c|}
\hline 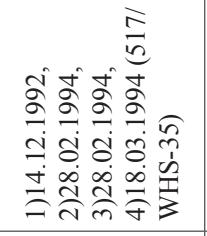 & 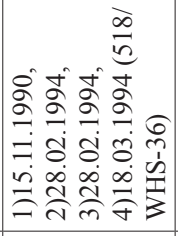 & 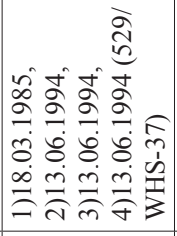 & 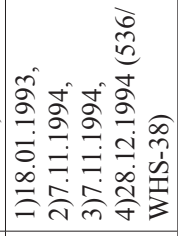 & 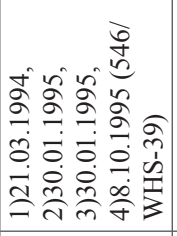 & 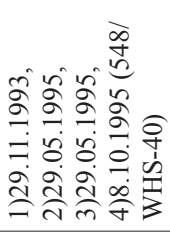 & 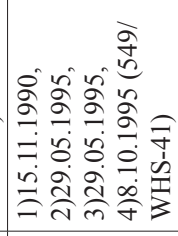 \\
\hline 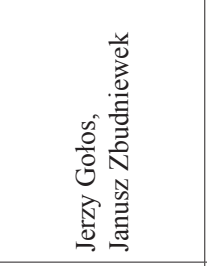 & 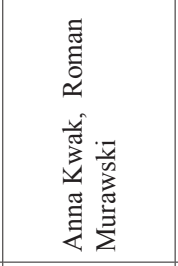 & 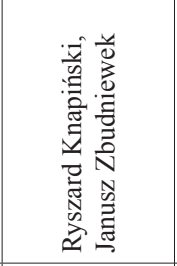 & 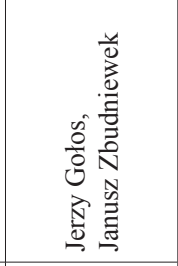 & 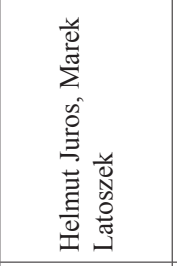 & 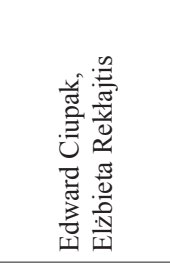 & 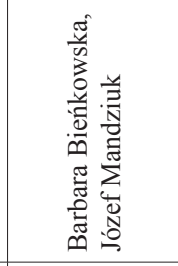 \\
\hline 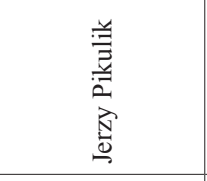 & 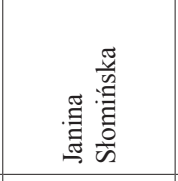 & 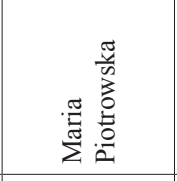 & 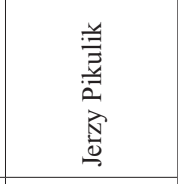 & 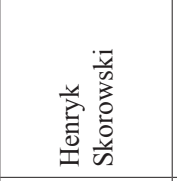 & 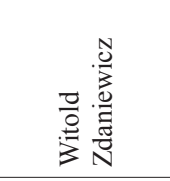 & 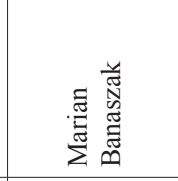 \\
\hline 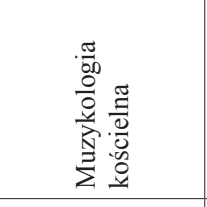 & 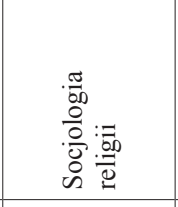 & 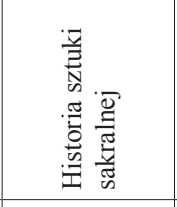 & 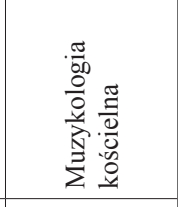 & 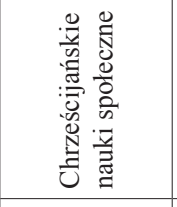 & 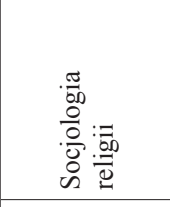 & 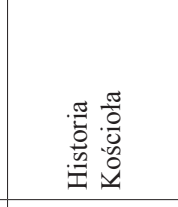 \\
\hline 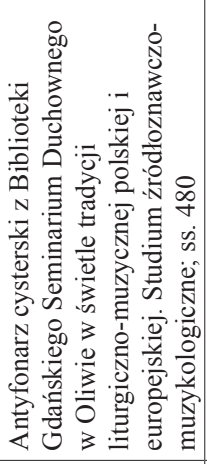 & 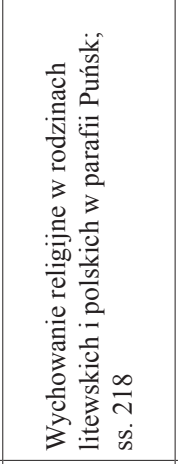 & 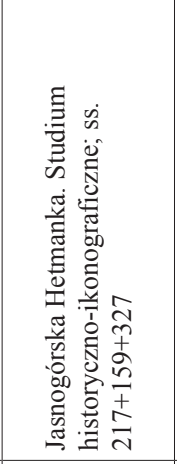 & 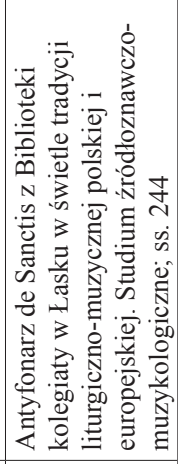 & 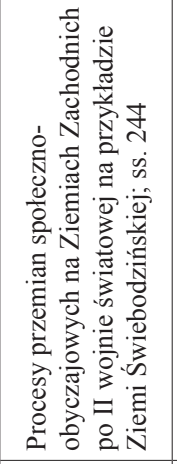 & 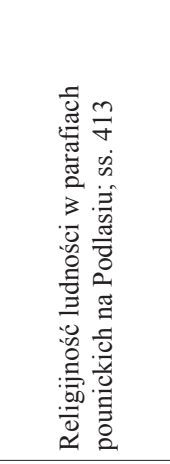 & 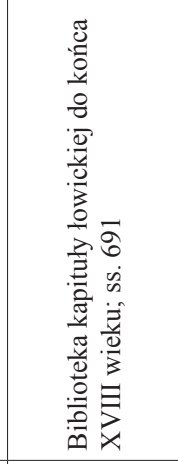 \\
\hline 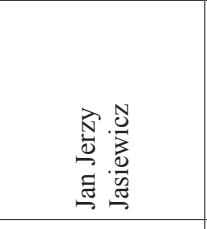 & 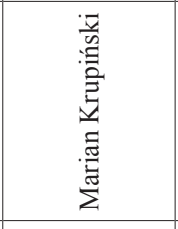 & 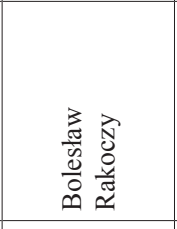 & 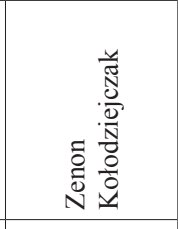 & 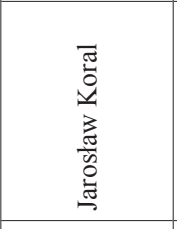 & 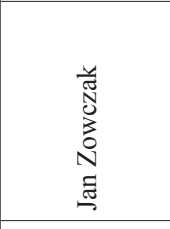 & 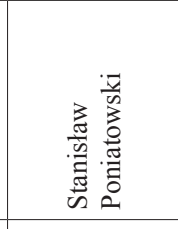 \\
\hline 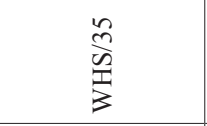 & 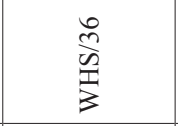 & $\begin{array}{l}\hat{m} \\
\frac{n}{n} \\
\frac{1}{3}\end{array}$ & $\begin{array}{l}\infty \\
\frac{1}{2} \\
\frac{1}{3} \\
\frac{1}{3}\end{array}$ & $\begin{array}{c}\frac{m}{3} \\
\frac{1}{1} \\
\frac{1}{3}\end{array}$ & $\frac{\frac{9}{9}}{\frac{10}{17}}$ & $\begin{array}{l}\frac{F}{5} \\
\frac{5}{3} \\
\frac{17}{3}\end{array}$ \\
\hline 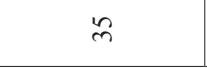 & $\stackrel{m}{\circ}$ & n & $\stackrel{\infty}{m}$ & हे & q & $\bar{F}$ \\
\hline
\end{tabular}




\begin{tabular}{|c|c|c|c|c|c|c|}
\hline 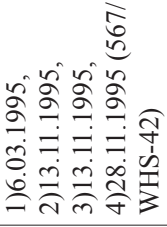 & 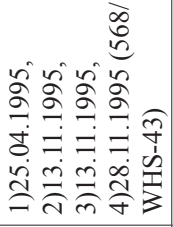 & 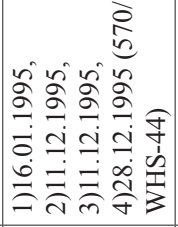 & 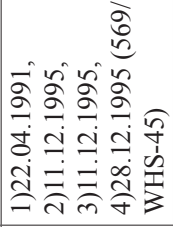 & 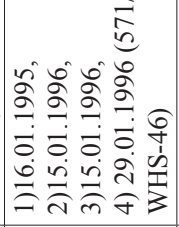 & 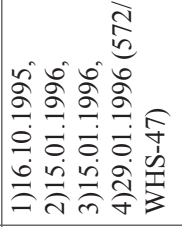 & 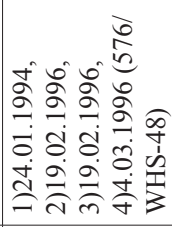 \\
\hline 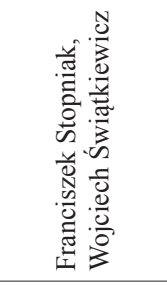 & 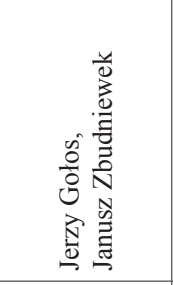 & 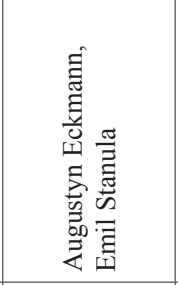 & 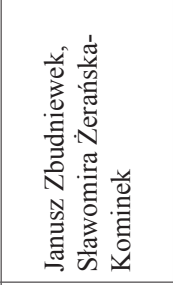 & 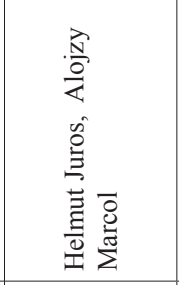 & 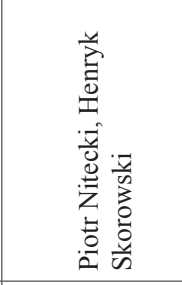 & 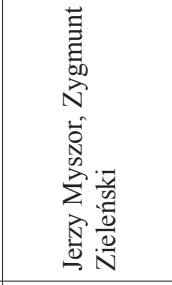 \\
\hline 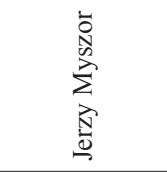 & 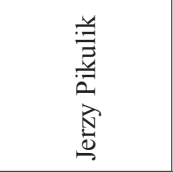 & 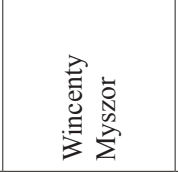 & 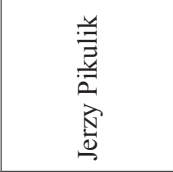 & $\begin{array}{l}\frac{n}{2} \\
\frac{\pi}{2} \\
\frac{\pi}{0} \\
\frac{\pi}{4}\end{array}$ & 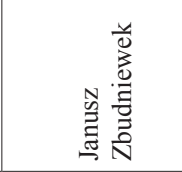 & 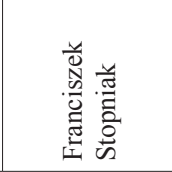 \\
\hline 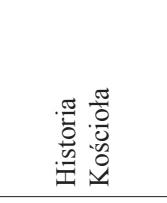 & 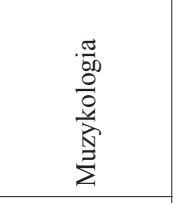 & 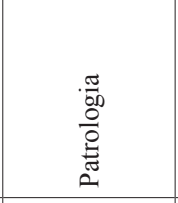 & 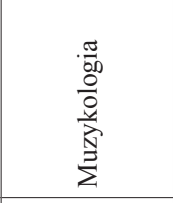 & 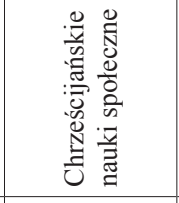 & 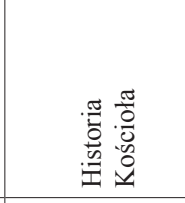 & 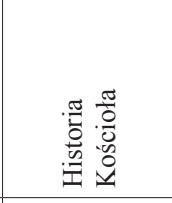 \\
\hline 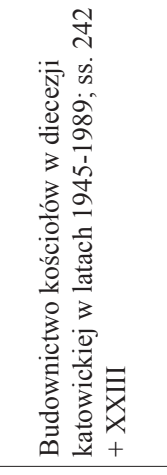 & 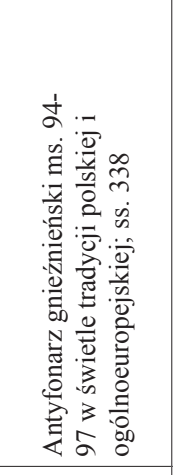 & 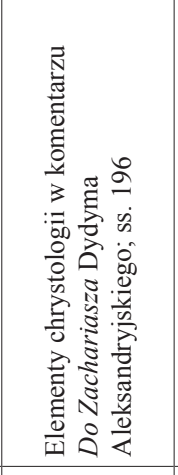 & 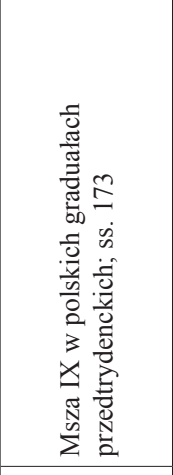 & 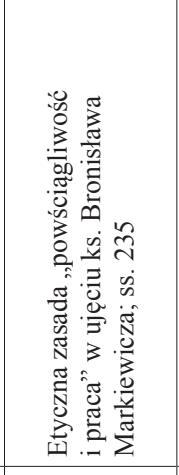 & 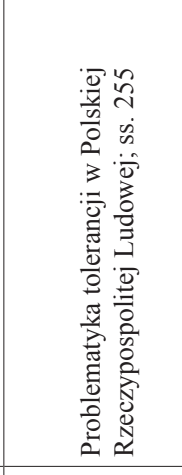 & 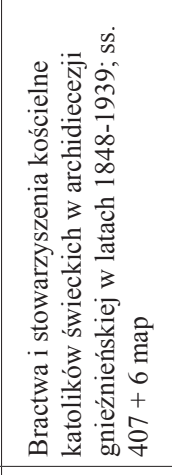 \\
\hline 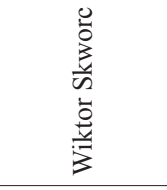 & 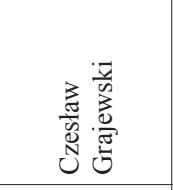 & 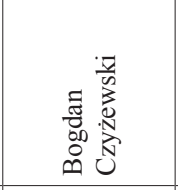 & 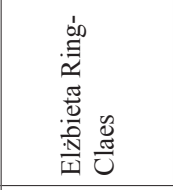 & 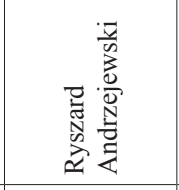 & 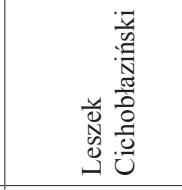 & 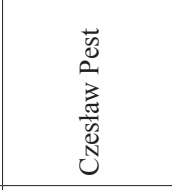 \\
\hline 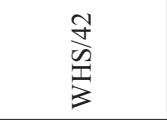 & 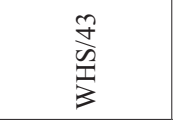 & $\begin{array}{l}\frac{J}{\Delta} \\
\frac{1}{0} \\
3\end{array}$ & $\frac{n}{\frac{9}{5}}$ & $\begin{array}{l}\frac{0}{1} \\
\frac{1}{3} \\
3\end{array}$ & 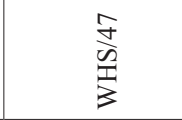 & 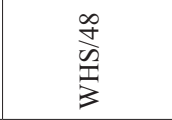 \\
\hline F & $\tilde{\gamma}$ & \& & if & fo & F & $\stackrel{\infty}{+}$ \\
\hline
\end{tabular}




\begin{tabular}{|c|c|c|c|c|c|c|}
\hline 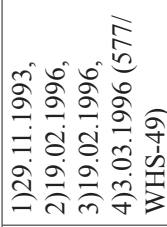 & 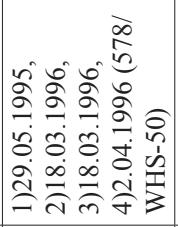 & 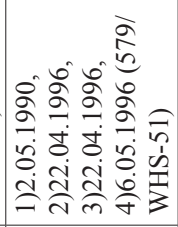 & 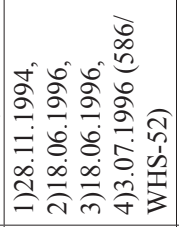 & 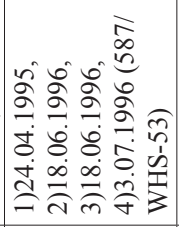 & 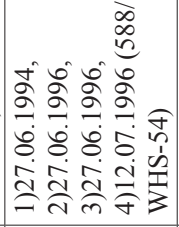 & 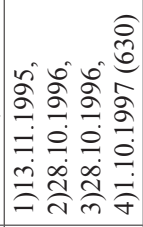 \\
\hline 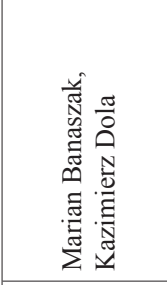 & 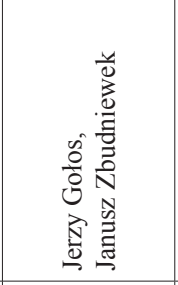 & 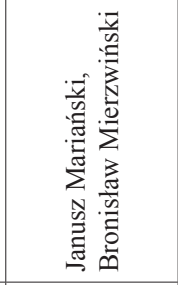 & 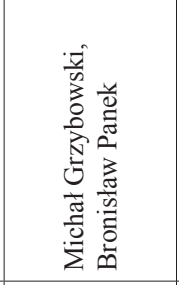 & 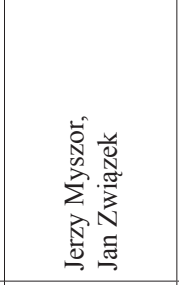 & 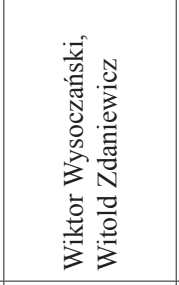 & 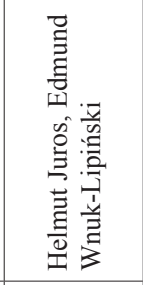 \\
\hline 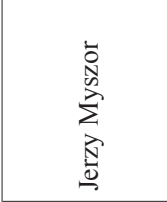 & 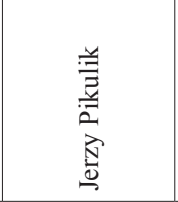 & 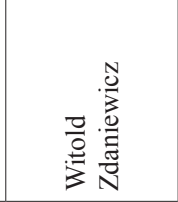 & 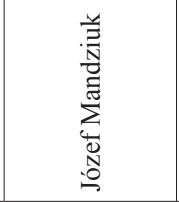 & 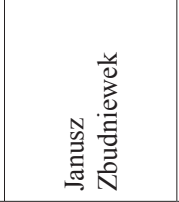 & 营泀 & 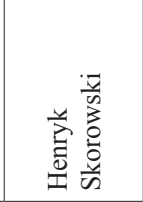 \\
\hline 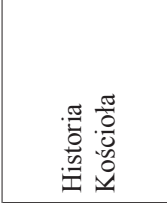 & 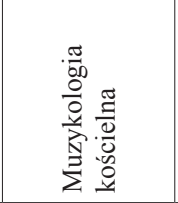 & 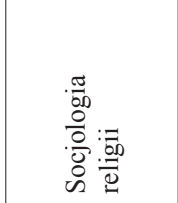 & 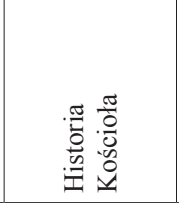 & 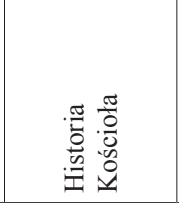 & 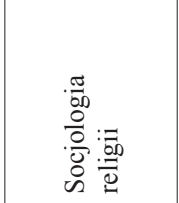 & 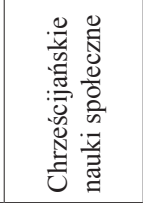 \\
\hline 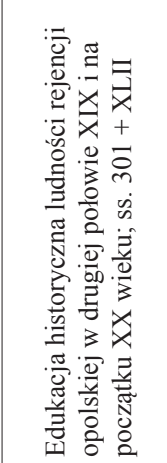 & 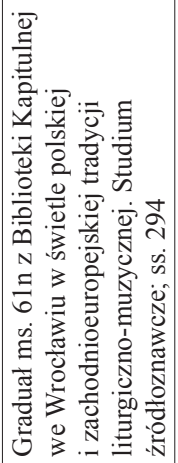 & 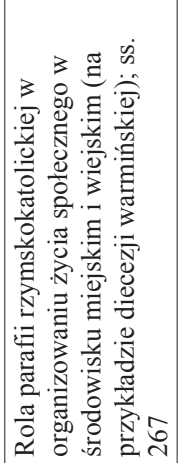 & 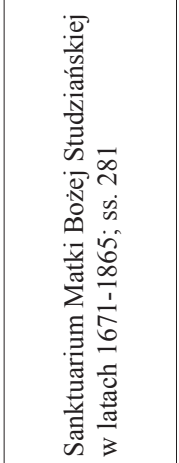 & 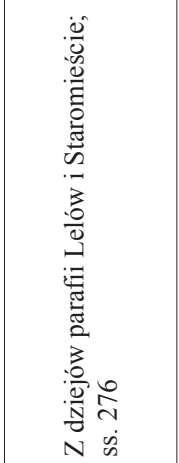 & 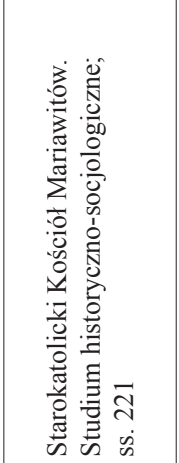 & 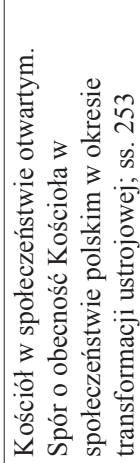 \\
\hline 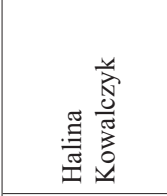 & 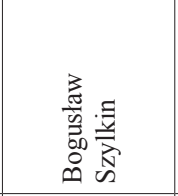 & 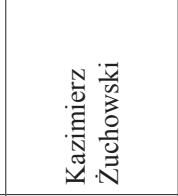 & 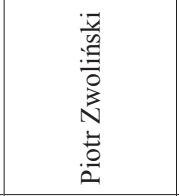 & 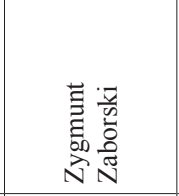 & 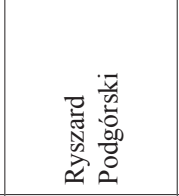 & 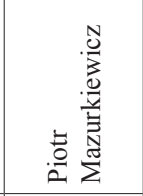 \\
\hline $\begin{array}{l}\frac{a}{d} \\
\text { 吾 } \\
3\end{array}$ & $\begin{array}{l}i n \\
\text { in } \\
\vdots \\
3\end{array}$ & $\begin{array}{l}\frac{n}{5} \\
\frac{1}{3} \\
3\end{array}$ & $\frac{N}{n}$ & $\begin{array}{l}n \\
\frac{n}{n} \\
3 \\
3\end{array}$ & $\begin{array}{l}\frac{1}{n} \\
\text { 吾 } \\
3\end{array}$ & $\frac{n}{n}$ \\
\hline gे & in & $\bar{n}$ & $\approx$ & $\hat{n}$ & 品 & $n$ \\
\hline
\end{tabular}




\begin{tabular}{|c|c|c|c|c|c|c|c|}
\hline 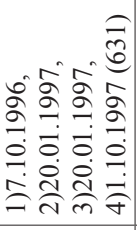 & 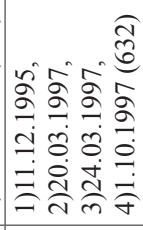 & 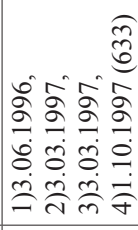 & 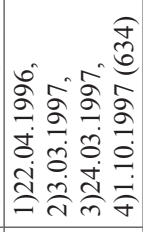 & 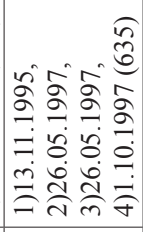 & 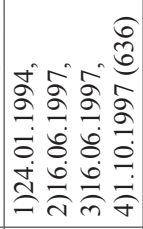 & 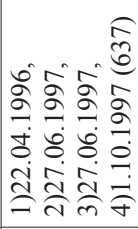 & 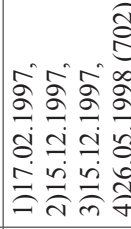 \\
\hline 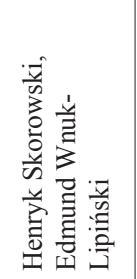 & 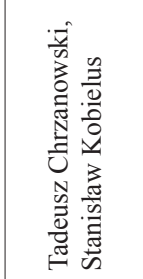 & 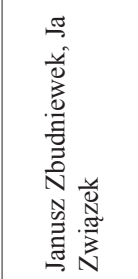 & 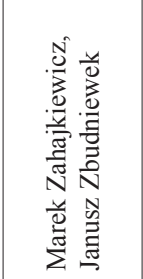 & 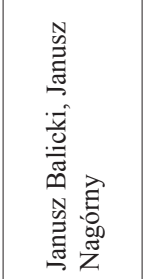 & 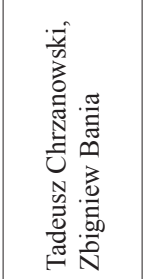 & 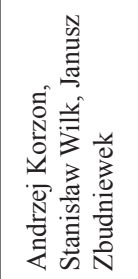 & 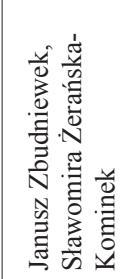 \\
\hline 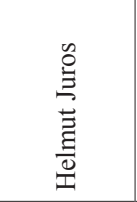 & 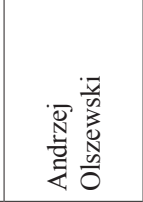 & 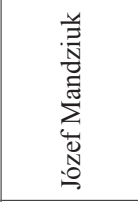 & 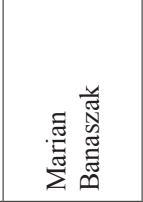 & 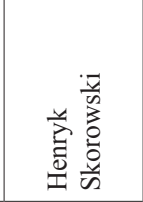 & 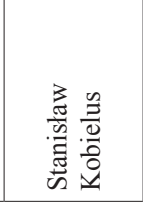 & 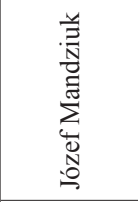 & 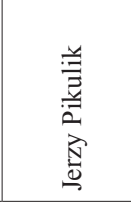 \\
\hline 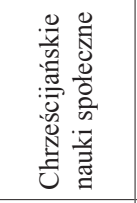 & 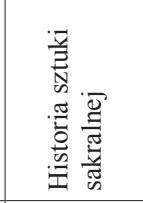 & 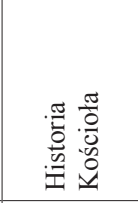 & 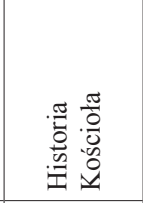 & 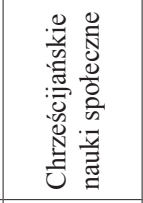 & 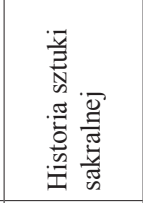 & 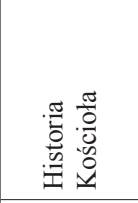 & 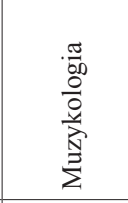 \\
\hline 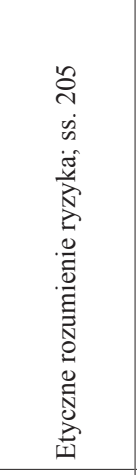 & 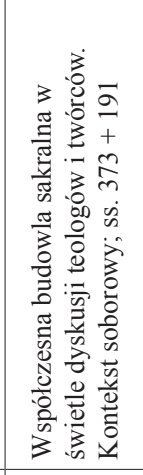 & 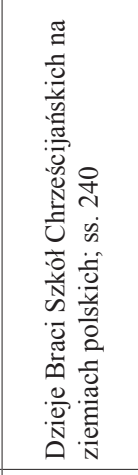 & 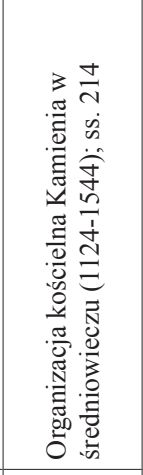 & 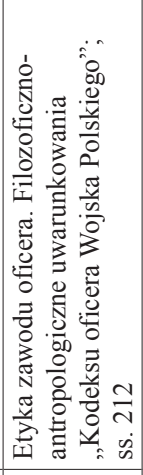 & 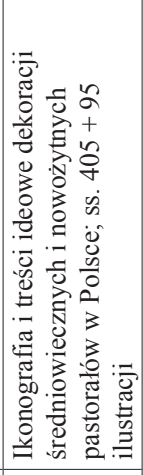 & 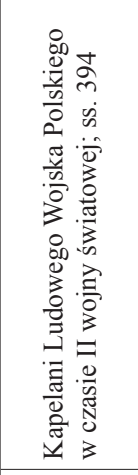 & 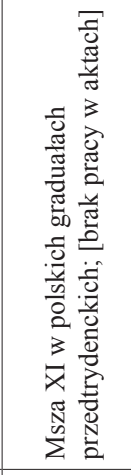 \\
\hline 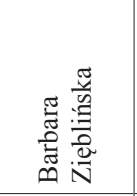 & 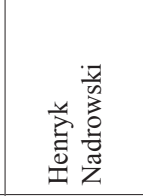 & 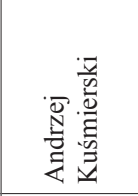 & 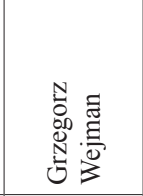 & 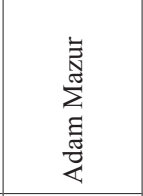 & 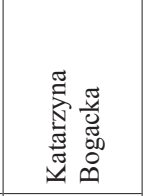 & 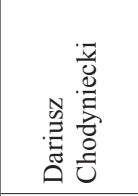 & 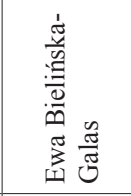 \\
\hline $\begin{array}{l}\frac{0}{n} \\
\frac{1}{3} \\
3\end{array}$ & $\begin{array}{l}n \\
\frac{n}{2} \\
\frac{1}{3}\end{array}$ & $\begin{array}{l}\infty \\
\infty \\
\infty \\
\\
3\end{array}$ & $\begin{array}{l}\frac{a}{n} \\
\frac{2}{1} \\
3\end{array}$ & $\begin{array}{l}8 \\
0 \\
0 \\
1 \\
3\end{array}$ & $\begin{array}{l}\overline{0} \\
5 \\
0 \\
3 \\
3\end{array}$ & 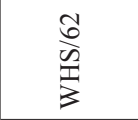 & 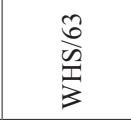 \\
\hline$\stackrel{n}{n}$ & in & $\stackrel{\infty}{n}$ & in & 8 & $\sqrt{6}$ & $\widehat{\sigma}$ & (6) \\
\hline
\end{tabular}




\begin{tabular}{|c|c|c|c|c|c|c|c|}
\hline 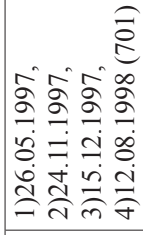 & 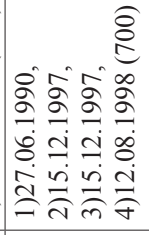 & 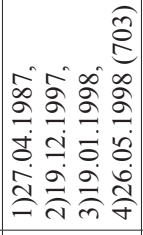 & 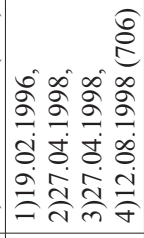 & 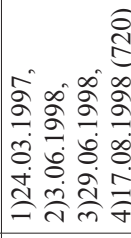 & 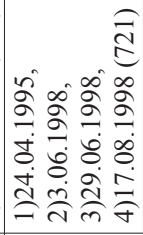 & 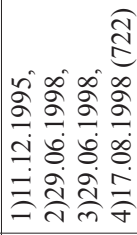 & 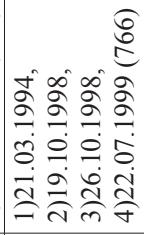 \\
\hline 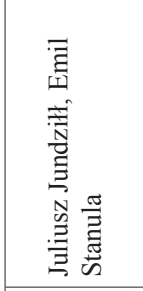 & 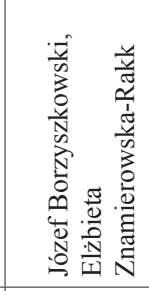 & 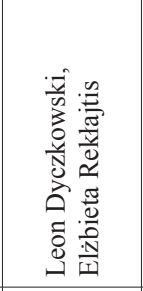 & 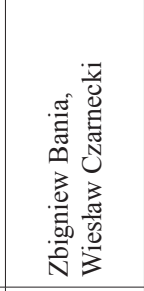 & 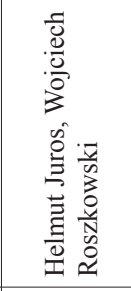 & 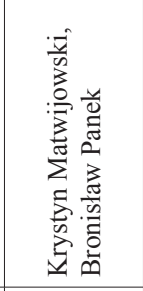 & 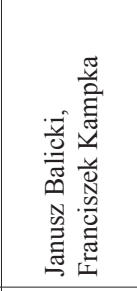 & 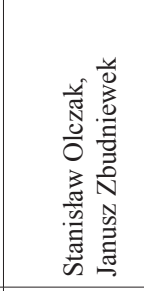 \\
\hline 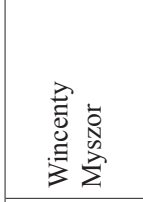 & 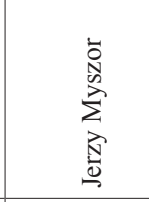 & 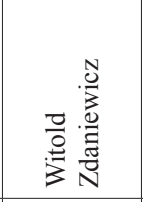 & 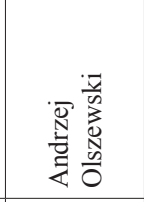 & $\begin{array}{l}\frac{0}{2} \\
\frac{1}{2} \\
\frac{\pi}{0} \\
.0 \\
\frac{0}{2}\end{array}$ & 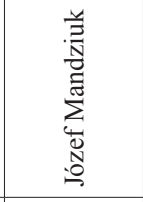 & 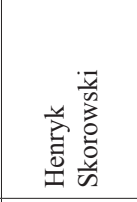 & 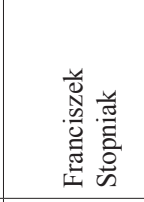 \\
\hline 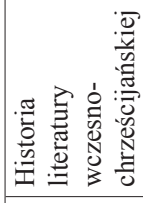 & 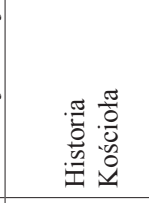 & $\begin{array}{l}\frac{\pi}{60} \\
\frac{0}{0}:= \\
\frac{0}{0}:= \\
\mathscr{0}:=\end{array}$ & 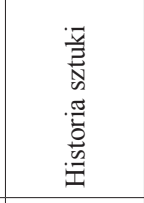 & 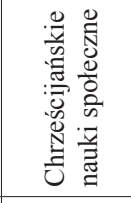 & 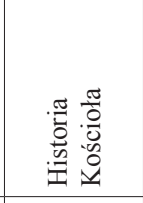 & 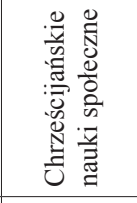 & 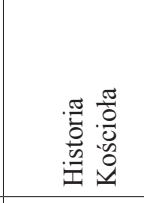 \\
\hline 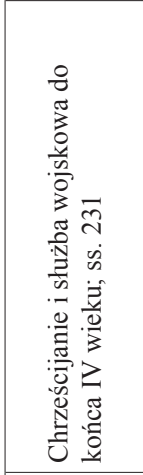 & 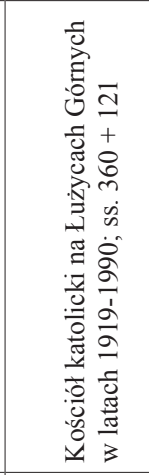 & 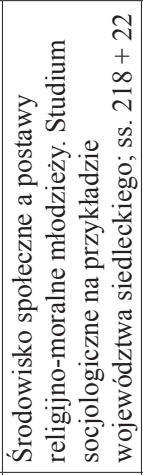 & 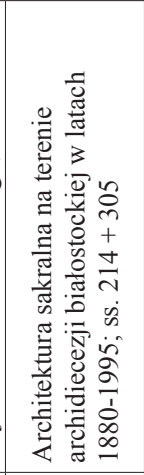 & 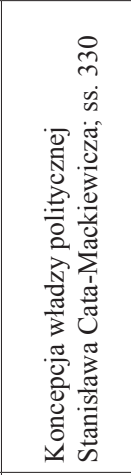 & 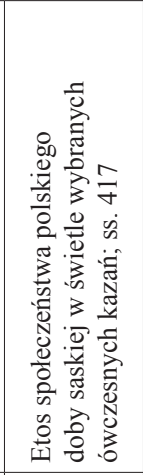 & 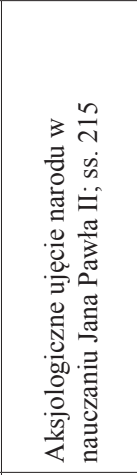 & 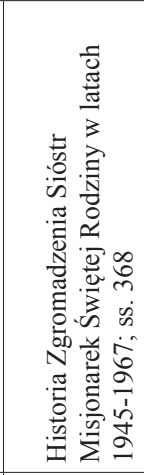 \\
\hline 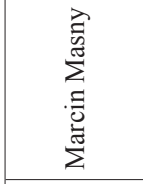 & 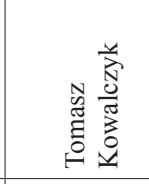 & 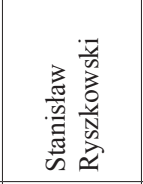 & 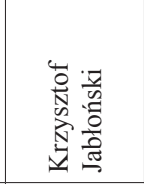 & 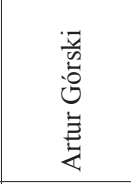 & 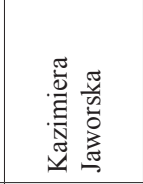 & 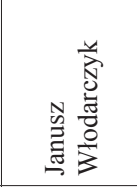 & 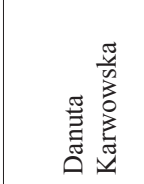 \\
\hline 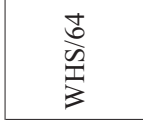 & $\begin{array}{l}n \\
0 \\
20 \\
3 \\
3\end{array}$ & $\begin{array}{l}0 \\
0 \\
01 \\
11 \\
3\end{array}$ & $\begin{array}{l}\hat{6} \\
\frac{1}{1} \\
3\end{array}$ & $\begin{array}{l}\infty \\
0 \\
0 \\
01 \\
3\end{array}$ & $\begin{array}{l}\frac{a}{0} \\
\text { No } \\
3\end{array}$ & $\begin{array}{l}\frac{1}{2} \\
\text { 垔 } \\
3\end{array}$ & $\begin{array}{l}\frac{1}{2} \\
0 \\
3 \\
3\end{array}$ \\
\hline t & 6 & 8 & $\hat{\sigma}$ & $\infty$ & 8 & $尺$ & F \\
\hline
\end{tabular}




\begin{tabular}{|c|c|c|c|c|c|c|c|}
\hline 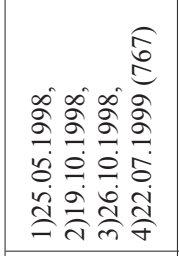 & 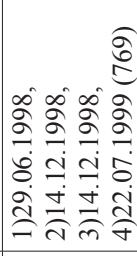 & 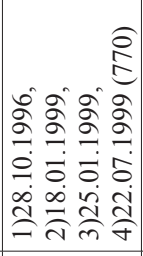 & 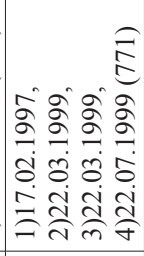 & 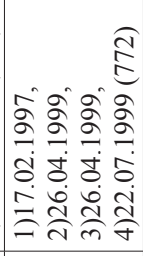 & 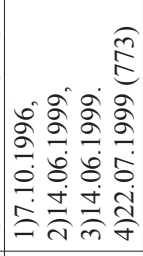 & 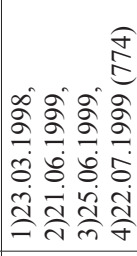 & 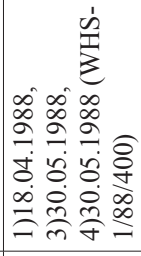 \\
\hline 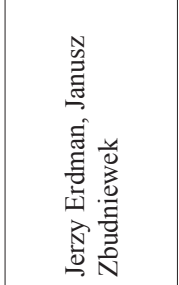 & 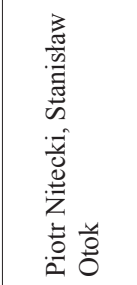 & 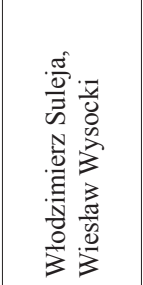 & 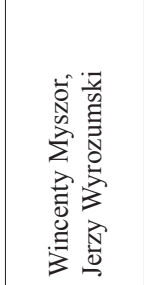 & 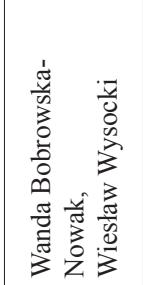 & 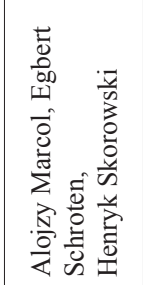 & 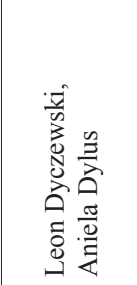 & 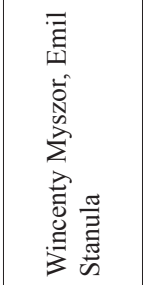 \\
\hline 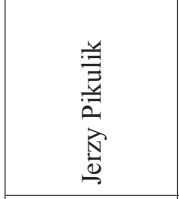 & 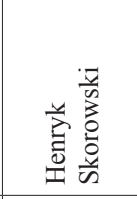 & 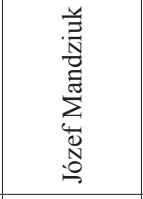 & 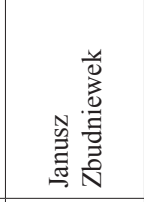 & 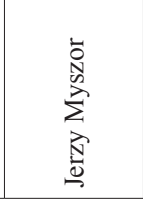 & $\begin{array}{l}\frac{0}{3} \\
\frac{1}{d} \\
\frac{\pi}{0} \\
\frac{0}{3}\end{array}$ & 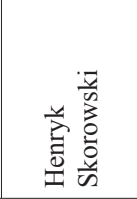 & 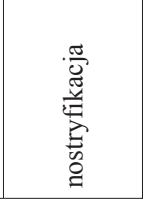 \\
\hline 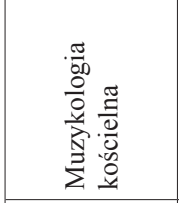 & 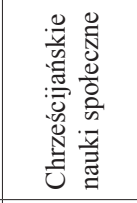 & 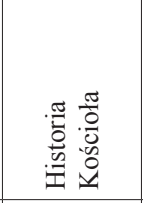 & 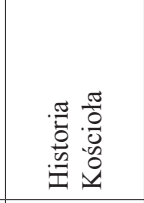 & 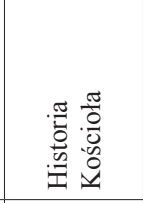 & 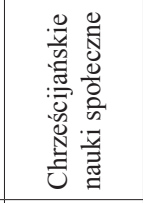 & 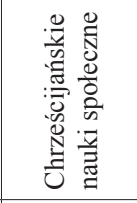 & $\begin{array}{l}\frac{\pi}{60} \\
00 \\
0 \\
0 \\
0 \\
0 \\
0\end{array}$ \\
\hline 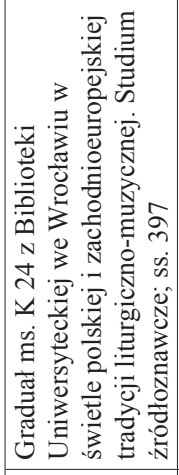 & 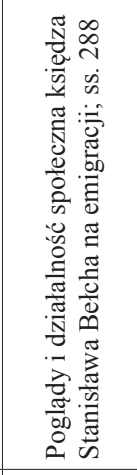 & 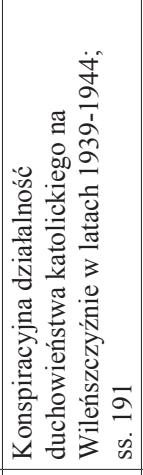 & 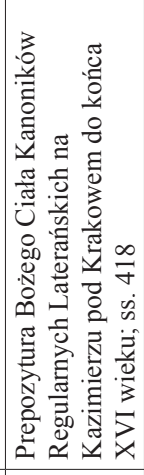 & 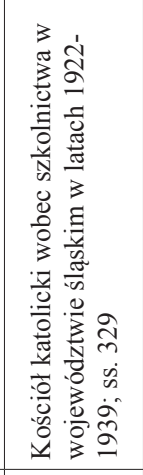 & 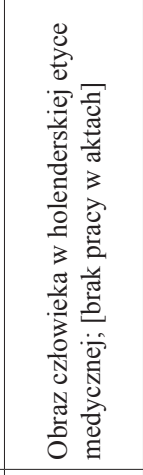 & 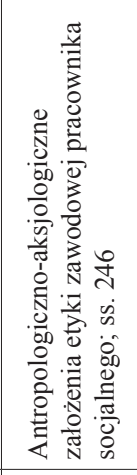 & 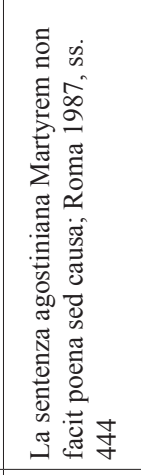 \\
\hline 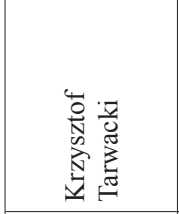 & 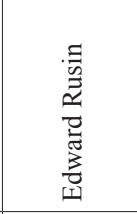 & 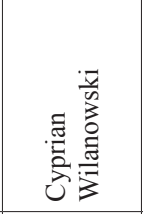 & 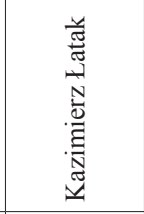 & 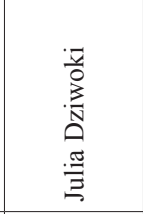 & 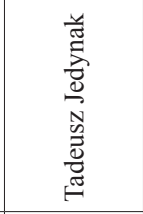 & 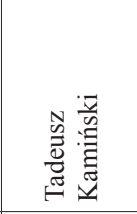 & 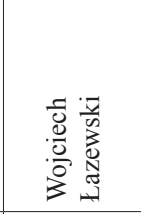 \\
\hline$\frac{N}{N}$ & $\frac{m}{\frac{m}{20}}$ & 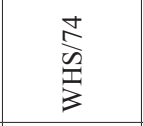 & $\begin{array}{l}\frac{n}{5} \\
\frac{2}{1} \\
\frac{1}{3}\end{array}$ & $\begin{array}{l}0 \\
\frac{N}{20} \\
\frac{1}{3} \\
3\end{array}$ & $\frac{N}{\hat{2}}$ & $\begin{array}{l}\frac{\infty}{2} \\
\stackrel{\infty}{1} \\
\sum_{1}^{1}\end{array}$ & $\frac{2}{\frac{2}{2}}$ \\
\hline $\mathbb{N}$ & 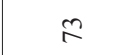 & i & $\approx$ & 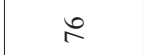 & $\approx$ & 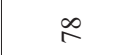 & 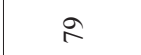 \\
\hline
\end{tabular}




\begin{tabular}{|c|c|c|c|c|c|c|c|}
\hline 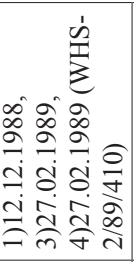 & 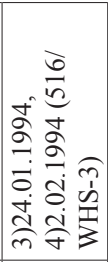 & 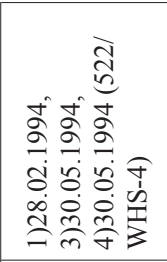 & 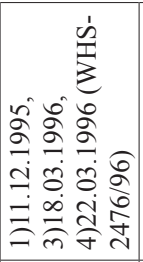 & 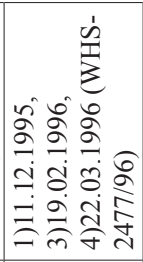 & 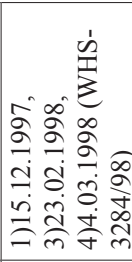 & 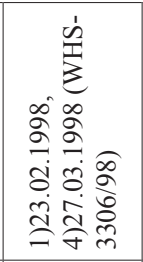 & 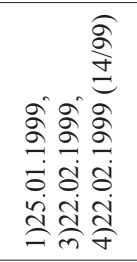 \\
\hline 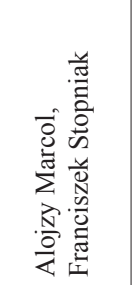 & 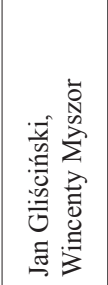 & 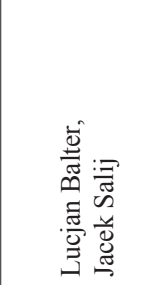 & 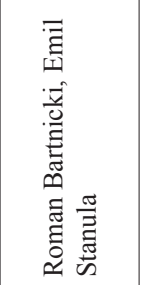 & 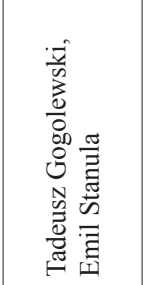 & 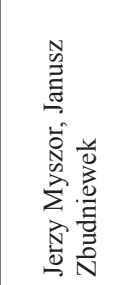 & 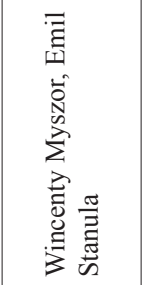 & 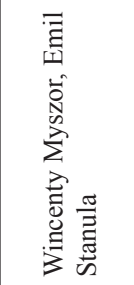 \\
\hline 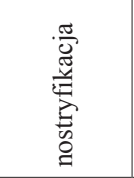 & 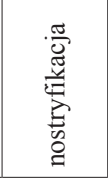 & 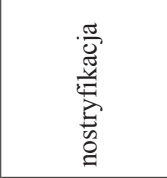 & 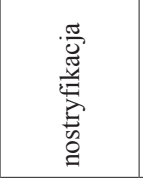 & 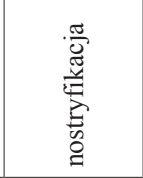 & 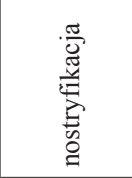 & 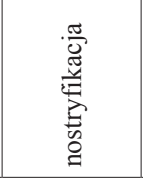 & 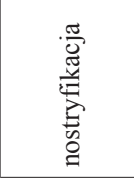 \\
\hline $\begin{array}{l}\frac{\pi}{60} \\
\frac{0}{0} \\
\frac{0}{8} \\
0 \\
0\end{array}$ & 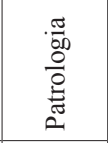 & $\begin{array}{l}. \frac{\pi}{60} \\
0 \\
0 \\
0 \\
0 \\
0 \\
0\end{array}$ & 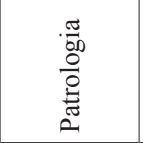 & 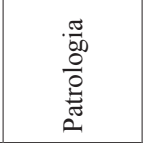 & 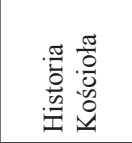 & 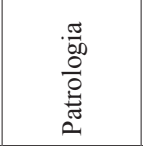 & $\begin{array}{l}\frac{\pi}{00} \\
0 \\
0 \\
0 \\
0 \\
0\end{array}$ \\
\hline 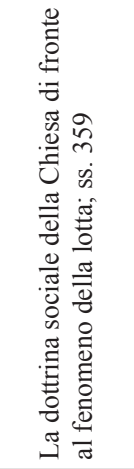 & 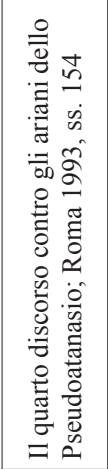 & 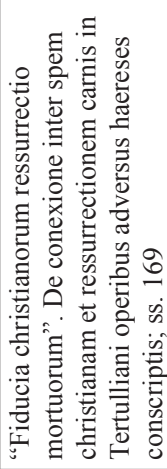 & 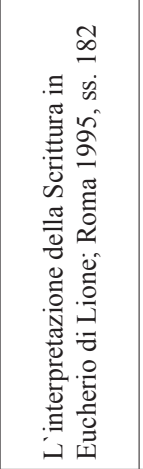 & 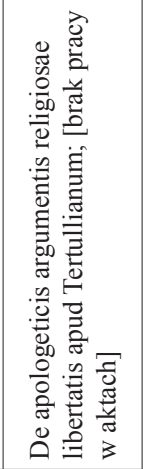 & 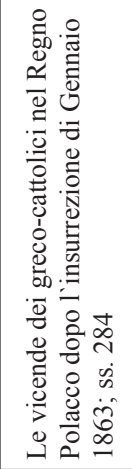 & 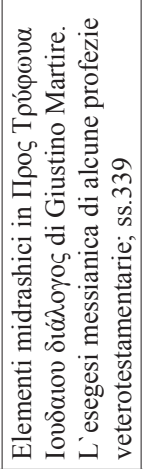 & 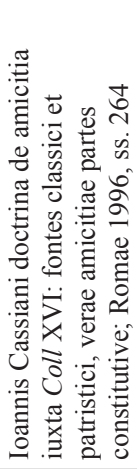 \\
\hline 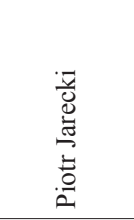 & 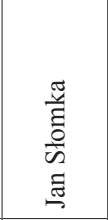 & 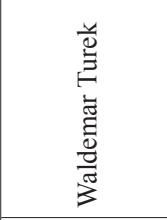 & 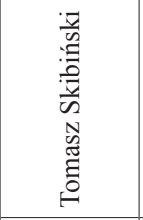 & 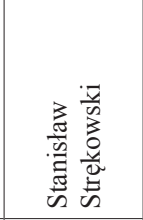 & 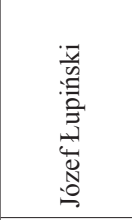 & 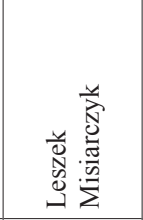 & 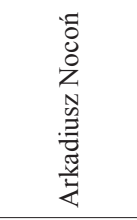 \\
\hline $\begin{array}{l}\frac{\infty}{\infty} \\
\sqrt{3} \\
3\end{array}$ & $\begin{array}{l}\bar{\infty} \\
\frac{\infty}{n} \\
3 \\
3\end{array}$ & $\frac{\infty}{\infty}$ & $\begin{array}{l}\infty \\
\infty \\
\infty \\
1 \\
3\end{array}$ & $\begin{array}{l}+ \\
\infty \\
2 \\
2 \\
1\end{array}$ & $\begin{array}{l}n \\
\infty \\
\infty \\
3 \\
3\end{array}$ & $\begin{array}{l}\infty \\
\infty \\
\infty \\
11 \\
3\end{array}$ & $\begin{array}{l}\hat{\infty} \\
\frac{\infty}{\omega} \\
3\end{array}$ \\
\hline$\triangleright$ & $\bar{\infty}$ & $\tilde{\infty}$ & $\mathscr{\infty}^{2}$ & 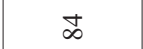 & $\mathscr{\infty}$ & 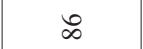 & $\hat{\infty}$ \\
\hline
\end{tabular}




\begin{tabular}{|c|c|c|c|c|c|c|c|}
\hline 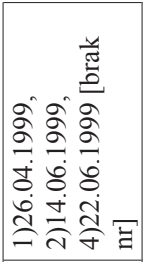 & 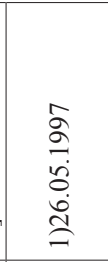 & 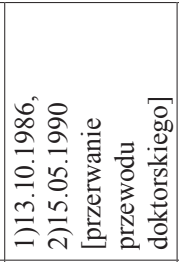 & 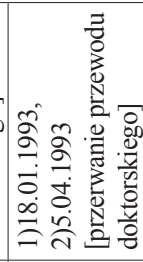 & 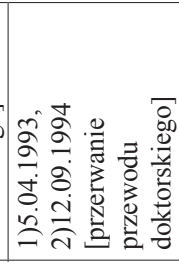 & 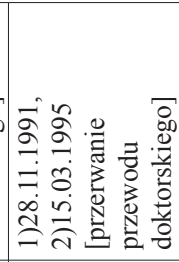 & $\begin{array}{l}\stackrel{\circ}{\circ} \\
\frac{1}{0} \\
\stackrel{0}{0}\end{array}$ & 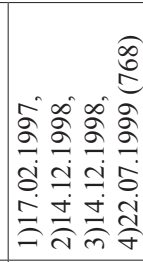 \\
\hline 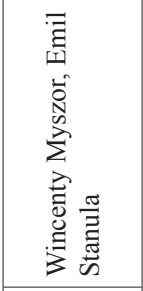 & & 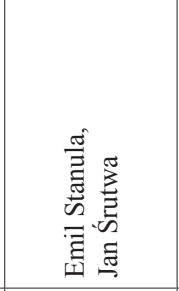 & 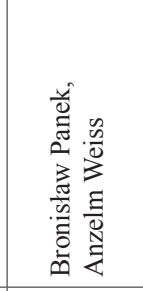 & 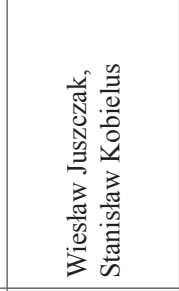 & & & 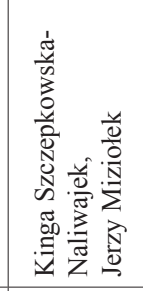 \\
\hline 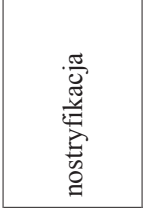 & 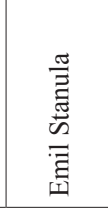 & 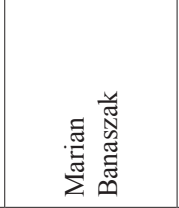 & 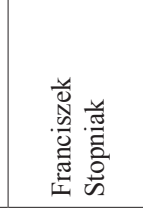 & 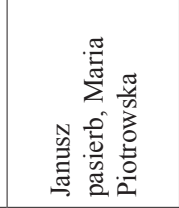 & 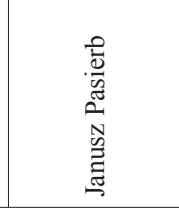 & 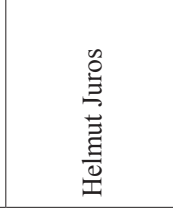 & 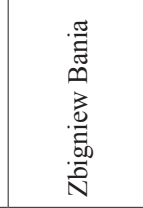 \\
\hline $\begin{array}{l}\frac{\pi}{60} \\
0 \\
0 \\
0 \\
0 \\
0 \\
0\end{array}$ & $\begin{array}{l}\frac{\pi}{60} \\
\frac{0}{0} \\
0 \\
0 \\
0\end{array}$ & 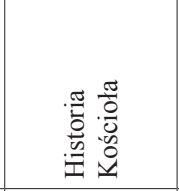 & 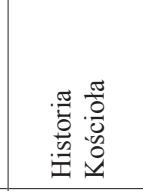 & 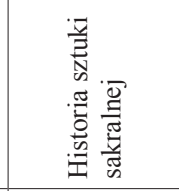 & 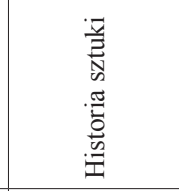 & & 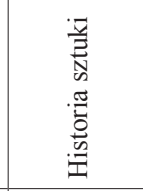 \\
\hline 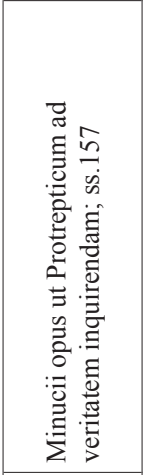 & 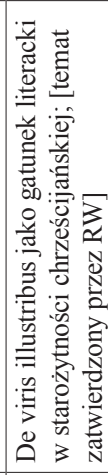 & 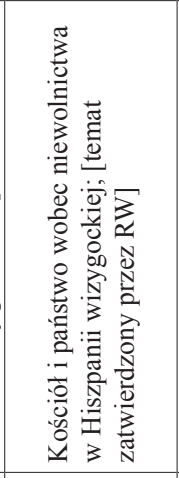 & 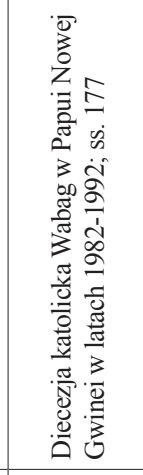 & 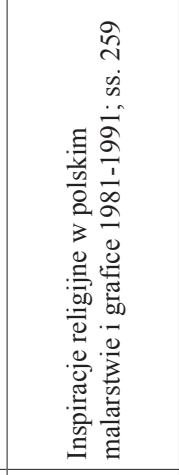 & 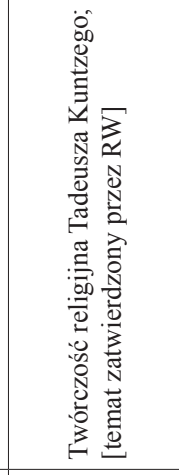 & 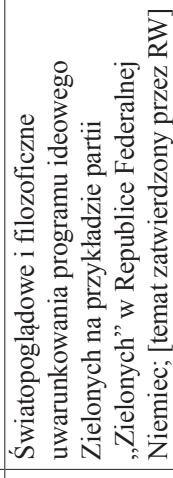 & 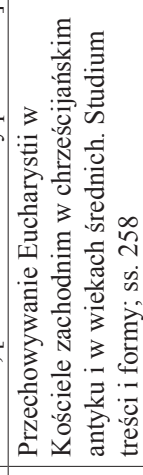 \\
\hline 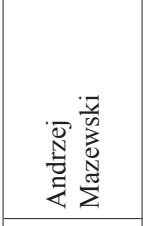 & 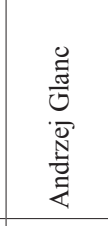 & 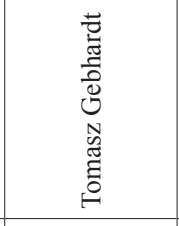 & 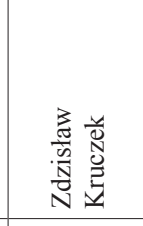 & 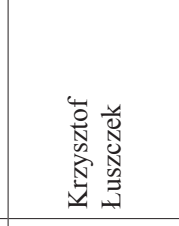 & 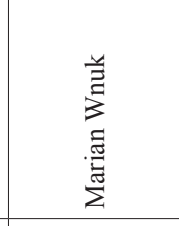 & 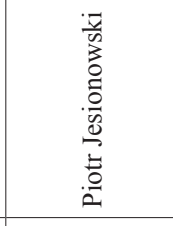 & 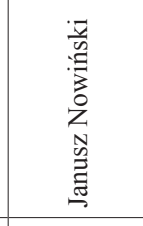 \\
\hline $\begin{array}{l}\infty \\
\infty \\
\infty \\
\infty \\
1\end{array}$ & $\begin{array}{l}\frac{2}{\infty} \\
\text { की } \\
1 \\
3\end{array}$ & $\frac{8}{\frac{2}{2}}$ & $\begin{array}{l}\bar{a} \\
\frac{2}{3} \\
\frac{1}{3}\end{array}$ & 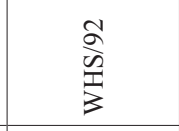 & $\frac{n}{\frac{n}{2}}$ & $\frac{+}{2}$ & 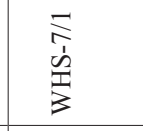 \\
\hline$\infty$ & $\infty$ & \& & $\bar{a}$ & $\alpha$ & $\hat{\alpha}$ & ఫ & 2 \\
\hline
\end{tabular}




\title{
RECORDS OF THE REGISTRATION AND CONFERMENT PROCEDURE FOR A DOCTORAL AND POSTDOCTORAL DEGREES OF THE FACULTY OF HISTORICAL AND SOCIAL STUDIES ON THE ACADEMY OF CATHOLIC THEOLOGY IN WARSAW
}

\author{
Summary \\ Records of doctoral proceedings of the Faculty of Historical and Social Studies contained in the \\ archive of Cardinal Stefan Wyszyński University include not only the opened and completed doc- \\ toral proceedings of the faculty but also the records of recognition of doctoral degrees granted by \\ foreign academic institutions. There are in total 89 archived units. There are supplemented by doc- \\ toral proceedings, which were opened but not completed for a variety of reasons - 6 units. Together \\ they span the years 1973 to 1999 . The complete documentation can be seen in Table 1. The records \\ hare been filed according to their signatures following the rearrangement and cataloguing of the \\ archive. They are therefore filed chronologically. The Table shows the main elements of the doc- \\ toral proceedings: \\ - the signed records, \\ - doctorant's name, \\ - thesis title, \\ - number of pages in each volume of the thesis, \\ - the discipline in which the doctorate was awarded, \\ - the supervisor's name, \\ - the names of the reviewers, \\ - commencement of the proceedings, \\ - the date of the examination, \\ - the date of the Faculty Board's decision to award the degree, \\ - the date and number of the doctoral certificate. \\ The information in this article is primarily intended for those researching the history and stud- \\ ies carried out in the faculty.
}

